\title{
Building adaptive capacity in a coastal region experiencing global change
} Fred A. Johnson $^{1,2}, \underline{\text { Mitchell J. Eaton }}^{3,4}$, Jessica Mikels-Carrasco $^{5}$ and David Case $^{5}$

\begin{abstract}
Coastal ecosystems in the eastern U.S. have been severely altered by human development, and climate change and other stressors are now further degrading the capacity of those ecological and social systems to remain resilient in the face of such disturbances. We sought to identify potential ways in which local conservation interests in the Lowcountry of South Carolina (USA) could participate in a social process of adaptation planning, and how that process might ultimately be broadened to engage a more diverse set of partners. We engaged participants through a combination of informal meetings, workshops, and other collaborative interactions to explore how the conservation community perceives and pursues its various missions, and how that community might confront the threats and opportunities in its future. Coproduction of knowledge and meaning were facilitated by collaborative scenario planning and strategic planning evaluation, which illuminated how the conservation community is integral to the broader governance of the region and highlighted how responses to forces of change are mediated through local culture, economics, and politics. We suggest an interpretation of conservation in which the fundamental objectives of both social and ecological systems might be prioritized in tandem, rather than narrowly focusing on environmental protection without consideration of the social landscape. Ultimately, adaptive capacity depends on the ability to act collectively, and social capital, trust, and organization greatly influence the capacity to act. Thus, we conclude that the presence of strong social networks, coordination and deliberation among diverse stakeholders, mechanisms for experiential feedback, and emphasis on social learning are key elements needed to build adaptive capacity. Central to the evolving perspective of governance of the commons is recognition that social and ecological systems are coupled; the issues and problems of one cannot be addressed without considering the consequences for the other. Moreover, a dominant theme emerging from our research and that of other scholars is the importance of culture and place attachment, which generates social cohesion and facilitates problem solving. These ideas have important implications for when, where, and how stakeholders are engaged to address the rapid changes being experienced by socialecological systems.
\end{abstract}

Key Words: adaptive capacity; climate change; coproduction; culture; panarchy; scenario planning; SWOT analysis; wicked problems

\section{INTRODUCTION}

Mitigating and adapting to the impacts of climate change and other drivers of global change present unprecedented challenges for environmental resource managers. Planning processes for what have been termed "wicked problems" can quickly be overwhelmed by the difficulty of accounting for multiple decision makers, competing values, complex interactions of social and ecological systems, and profound uncertainties regarding the future and society's ability to influence it. Rittel and Webber (1973) introduced the notion of "wicked" planning problems, which in addition to the features above, are characterized by: (1) the lack of a definitive problem formulation; (2) no finite set of decision alternatives; (3) a never-ending search for solutions; and (4) interdependencies with other wicked problems. Solutions to wicked problems do not usually arise from a systematic, linear process of planning, but from a social planning process involving multiple stakeholders, effective communication, visioning of alternative futures, and acceptance of diverse opinions (Camillus 2008, Johnson et al. 2016). Here and elsewhere, our reference to solutions should not be construed as optimal in any formal or informal sense because it is unlikely that consensus on societal objectives is achievable. Rather, solutions are plausible paths forward that could possibly represent incremental improvements over the status quo.

The goal of our research was to identify potential ways in which local conservation interests could participate in a process of adaptation planning and, ultimately, we sought to understand how that process might be broadened and enhanced to include a more diverse set of stakeholders (i.e., those other than conservation interests). We used a collaborative, coproductive approach to guide and inform our engagement. Under this framework, science and governance are understood to interact, whereby scientific information must be placed in contexts that produce distinctive cultural responses (Jasanoff 2004), and the diversity, richness, and challenges of local contexts are paramount in understanding how scientific information is acted upon (Hulme 2010). Our focus was on the early phase of social engagement, by bringing together various conservation interests and using a variety of tools for coproduction of knowledge and meaning, and by considering how the lessons learned could be helpful for engaging more diverse social interests.

Our hope is that these experiences will be helpful to those contemplating more systematic approaches to adaptation in social-ecological systems. We focused on coastal ecosystems in the eastern U.S., which have been severely altered by processes associated with human development, including drainage of coastal wetlands, land clearing, and the construction of seawalls and other structures that harden the coast (Stedman and Dahl 2008). Sea-level rise and the changing frequency of extreme events associated with climate change are now further degrading the capacity of those ecological and social systems to remain resilient in the face of disturbance (Arkema et al. 2013, USGRCP 2018).

Study context and problem statement

At the behest of several coastal National Wildlife Refuges (administered by the U.S. Fish and Wildlife Service), we chose as

${ }^{1}$ U.S. Geological Survey, Wetland and Aquatic Research Center, ${ }^{2}$ Aarhus University, Department of Bioscience, Denmark, ${ }^{3}$ U.S. Geological Survey, Southeast Climate Adaptation Science Center, ${ }^{4}$ North Carolina State University, Department of Applied Ecology, ${ }^{5}$ D. J. Case \& Associates 
a case study a region known as the Lowcountry, an area encompassing the coastal plain of South Carolina (Fig. 1). It is a region facing rapid environmental and societal change, with a rich historical and cultural heritage, and an active and diverse group of conservation interests (Halfacre 2013). Change has been an enduring feature of the Lowcountry. Correspondingly, community resilience and adaptability are striking characteristics of this region. Priorities of historical, cultural, and natural preservation are seen in response to chronic and catastrophic events, dating back as far as the Civil War to more recent events such as Hurricane Hugo in 1989. What has emerged is an active and vibrant conservation community that focuses as much on culture and quality of life as on ecological concerns (Halfacre 2013). The rich cultural heritage of the Lowcountry, fostered by a strong bond to the land and sea, has helped shape a conservation movement that is remarkably successful, especially in light of entrenched social and political conservatism and the primacy of private-property rights (Johnson et al. 2009, Halfacre 2013). For example, in the 1990s, the conservation community was at the forefront of a high-profile debate over economic development that would provide greater protection for open spaces and rural landscapes, which ultimately led to significant local and state environmental legislation (Halfacre 2013). The Lowcountry conservation community has become extremely diverse, with many sophisticated nongovernmental organizations (NGOs) providing strong leadership and promoting land-based livelihoods that help sustain the area's cultural heritage (Halfacre 2013). The conservation community in the Lowcountry embraces social learning (Clark et al. 2001), uses a diversity of approaches for achieving its conservation objectives, and takes advantage of strong social cohesion and mechanisms for collective action, all essential features of resilient and adaptive social-ecological systems (Adger et al. 2005a).

Fig. 1. South Carolina Lowcountry, Cape Romain National Wildlife Refuge (NWR), and Francis Marion National Forest (NF).

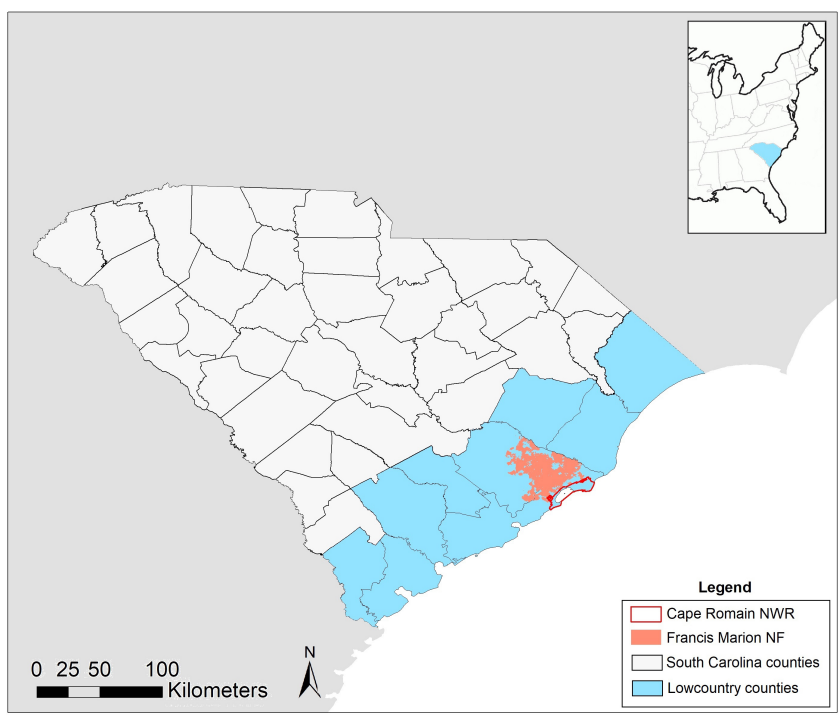

The Lowcountry's environmental wealth, rich cultural heritage, and quality of life have been a double-edged sword, however. Expanding tourism and population growth have placed strains on infrastructure, fueled urban sprawl, increased social vulnerability, amplified economic inequalities, and fanned racial tensions (Faulkenberry et al. 2000, Johnson and Floyd 2006, Johnson et al. 2009, Halfacre, 2013). Climate change is exacerbating these and other problems. Coastal ecosystems are naturally dynamic, but the confluence of rapid changes and increased exposure that comes with more people and expanding infrastructure produces greater risk of adverse consequences for Lowcountry social-ecological systems. Rapid sea-level rise is driving regular tidal flooding in the Charleston, South Carolina, metropolitan area and is contributing to the loss of coastal environments that provide multiple ecological goods and services, including critical habitat for fish and wildlife (Gardner et al. 1992, Daniels et al. 1993, Morris et al. 2002). Although the effect of climate change on the frequency of coastal storms is uncertain, sea-level rise amplifies the impact of recurrent hurricanes and nor'easters, which are rapidly altering the sediment-starved barrier islands that provide protection for the landscape, infrastructure, and people from the force of the open ocean (Stutz and Pilkey 2011). The large-scale nature of climate change presents the Lowcountry conservation community with a socalled "problem of fit," in which the scale of the problem is not matched by the scale at which local institutions can easily mitigate or adapt to impacts (Cumming et al. 2006, 2013). Therefore, we selected the broader Lowcountry region and its conservation community as a more appropriate match to the scale of these social-ecological challenges rather than focusing on the wildlife refuge as a single decision maker (Keeney 1992, Johnson et al. 2015).

Along with developing model-based tools to support coastal habitat management (e.g., Eaton et al. 2019), we used informal meetings, workshops, scenario planning (Peterson et al. 2003), and other collaborative tools to explore how the conservation community in the Lowcountry perceives and pursues its various missions, and how that community might confront the threats and opportunities in its future (Fig. 2). Our goal was to test a series of engagement activities and tools that were informed by several theoretical frameworks rather than the evaluation of a given social theory or analytical framework. Ultimately, we were interested in understanding how tenets of social-ecological theory might influence planning processes for adaptation to global change.

\section{Theoretical foundations used to inform engagement}

The search for solutions to wicked environmental problems has challenged the traditional view of humans as being apart from, but managers of, nature (Berkes 2010). That view has been replaced by the recognition that humans and the environment interact in complex ways over many levels of organization and scales of space and time (Gunderson et al. 1995, Holling 2001, Ludwig 2001, Walker and Salt 2006). This human and nature perspective (Mace 2014) means that the social-ecological system is the fundamental unit of analysis (Berkes 2010), with all the complexity that it entails. Accompanying this shift in perspective has been the emergence of the concept of resilience, which posits that all complex systems go through repeating, adaptive cycles of exponential change, stasis, collapse, and renewal; a process that 
ultimately sustains the system and its functions over time (Holling 2001, Gunderson and Holling 2002, Folke 2006). A panarchy is defined as a nested set of these adaptive cycles across space and time, such that phases of a cycle at one scale exert influence on the progression of phases at another (Holling 2001; see Fig. 7 therein).

Fig. 2. Possible stages of engagement for building adaptive capacity in social-ecological systems. Initial engagement with potential stakeholders involves listening sessions to identify additional stakeholders, uncover stakeholders knowledge and attitudes, and consideration of human behavior models to help design messages and activities appropriate for specific areas, issues, and audiences. Coproduction of alternative future scenarios, using the intuitive-logics process, can help promote social learning by generating shared perspectives of plausible futures, as well as providing a vehicle for problem solving and consensus building. A focus on ecological goods and services, using social, technological, environmental, economic, and political (STEEP) indicators to identify important drivers, can provide a common set of values shared by divergent stakeholders. A strategic planning tool (e.g., SWOT analysis) is employed for understanding the strengths and weaknesses of different stakeholder groups, and how that diversity can be exploited to formulate actions to confront threats and take advantage of opportunities. This is possibly followed by iterated engagement with stakeholders who have even more diverse interests in an ongoing process of social learning and adaptation. More detailed explanation of these components is found in text.

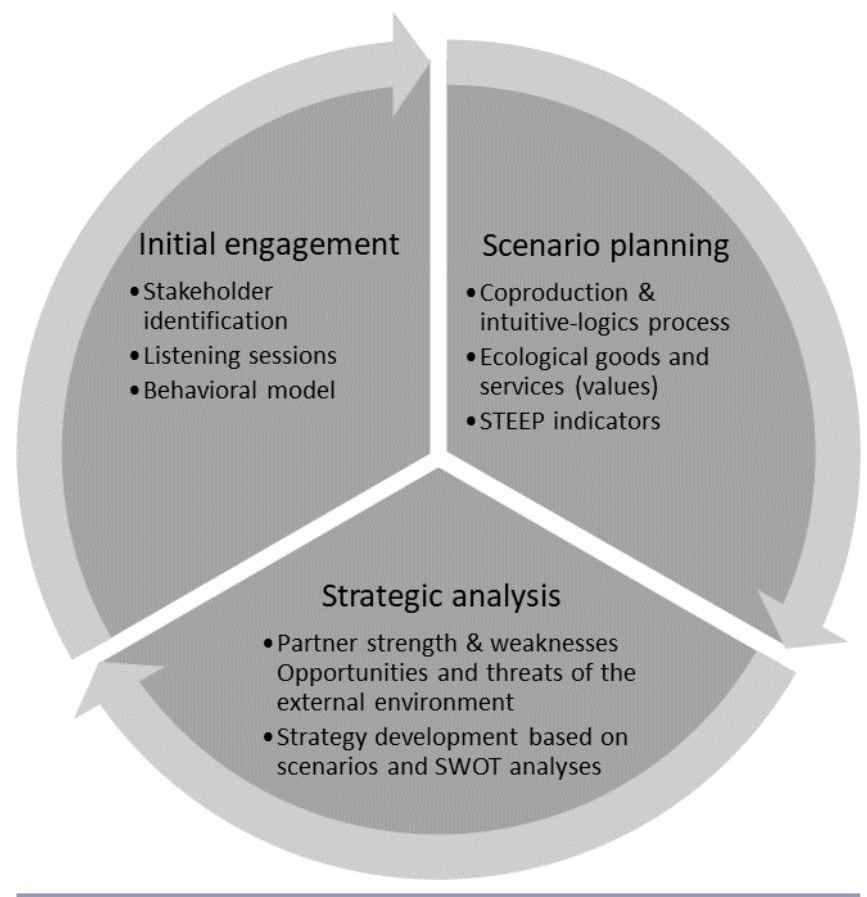

Panarchy theory has profound implications for governance of social-ecological systems (Gunderson and Holling 2002). First, it suggests there is no unique or manifest scale at which environmental problems can be analyzed and addressed.
Although the focus of an environmental problem may be local, sustaining the flow of ecological goods and services depends on events and drivers happening at other scales, whether in a local community or in global systems, which shape and constrain what is possible. Second, timing is everything. Episodic disturbances, such as the collapse of the U.S. housing market in 2008, produce both chaos and opportunity. The lesson from panarchy theory is to recognize when the social-ecological system is positioned for change, and then to stand ready as a catalyst by having a strong network of ideas, actors, and institutions (Olsson et al. 2006). Third, old notions of systems in equilibrium, with fixed forms of governance, are not congruent with the dynamic and unpredictable nature of social-ecological systems. The flow of ecological goods and services is constantly in flux and subject to occasional, often unpredictable, shocks. Adapting to this uncertainty requires more explicit assessments of risk, and adoption of robust policies and actions that are more likely to produce an acceptable flow of goods and services regardless of how the future unfolds (Lempert and Schlesinger 2000, Hall et al. 2012).

Finally, we note that notions of place attachment, sense of place, the role of culture, and sense-making in social discourse are increasingly being used to understand the complex interactions between society and the environment (Demeritt 2002, Cheng et al. 2003, Crane 2010), and how societies respond and adapt to change (Ney and Thompson 2000, Adger et al. 2009, 2013). Indeed, Cheng et al. (2003:87) argued that "natural resource politics is as much a contest over place meanings as it is a competition among interest groups over scarce resources." A sense of place is culturally constructed, and continuously reconstructed, through the interaction among biophysical attributes and processes, social and cultural meanings, and social and political processes (Burnett 1976, Canter 1977, Cheng et al. 2003). Because an individual's response is the basic unit of societal adaptation, engaging with diverse stakeholders in the face of such complexity requires recognition of a plurality of perspectives and views of the issues through differing values and social-ecological priorities (Cheng et al. 2003). Although many individuals and other entities have a stake in the issues of climate change, sea-level rise, and land-use change, they may also maintain different levels of actual and perceived agency to act on issues of concern (Ajzen 2002). By integrating social science practices (e.g., behavioral change theory such as described by the transtheoretical model [TTM]; Prochaska and Velicer 1997) with a coproductionist approach to problem definition and searching for solutions, planners may find that different perspectives among stakeholder are not insurmountable obstacles but may identify opportunities in which emergent solutions can arise.

\section{METHODS}

\section{Stakeholder participation and engagement}

We worked with the staff of Cape Romain National Wildlife Refuge to identify management agencies, conservation organizations, and other groups in the Lowcountry region concerned with social, natural resource, and global change issues that might have an interest in partnering with us. For our purposes here, we first engaged with those organizations that were likely to support similar social-ecological priorities. We entered into this engagement with the recognition that among a broad array of 
stakeholders, there would likely be divergent priorities, levels of interest, and capacity to act, and with perspectives ranging from local to national scales. We first wanted to understand the perspectives, priorities, and ongoing activities of these organizations and whether engaging with this proposed project would be beneficial to their conservation efforts. With this in mind, we invited groups to participate in the exploratory research activities based on their understanding of our goals and the fit with their mission objectives. Several groups expressed interest and enthusiasm to participate, leading to the formation of the Cape Romain Partnership for Coastal Protection (Partnership, hereafter) which included representation from Cape Romain National Wildlife Refuge, Francis Marion National Forest, South Carolina Department of Natural Resources, South Carolina Aquarium, The Nature Conservancy, National Oceanic and Atmospheric Administration Office for Coastal Management, Center for Heirs Property, Lowcountry Land Trust, and South Carolina Sea Grant Consortium.

As one of our first activities, participants engaged in a stakeholder analysis for the wider region. Participants identified as many socioeconomic interest groups and individuals as they could within the Lowcountry community; these were grouped into a smaller number of general sectors, which were then categorized by their relative interest in changes affecting the Lowcountry and their power to influence adaptation responses and the trajectory of their community, as perceived by Partnership members. The analysis provided a sense of the range of stakeholders that might be considered for future engagement, as well as the most effective forms of messaging and engagements to maximize interest.

\section{Scenario planning}

Scenario planning was developed in the 1960s as a way for organizations to cope with an uncertain future (Millett 1988). Scenarios are plausible descriptions of possible future states of the world, but they are not predictions or forecasts (Berkhout et al. 2002, Peterson et al. 2003, Rounsevell and Metzger 2010). Rather, they are intended to offer insights into what the future might hold in terms of the threats and opportunities facing an organization. Scenarios are typically formulated as narrative storylines, although they often are based on quantitative information. Organizations use alternative scenarios to foster a shared perspective of possible futures, from which robust solutions to complex problems can arise.

Scenario planning is increasingly being used to explore adaptation strategies to climate and other global change (Peterson et al. 2003, Duinker and Greig 2007, Tompkins et al. 2008, Rosentrater 2010, Sheppard et al. 2011, Cobb and Thompson 2012, Carlsen et al. 2013, National Park Service 2013). In this context, scenario planning can be a useful method to explore highly uncertain events; to incorporate diverse knowledge, interests, and opinions; as a method of collective learning; and as a communication tool for working with a diversity of stakeholders who may have widely varying interests (Berkhout et al. 2002, Peterson et al. 2003, Wiseman et al. 2011).

We conducted a 2-day scenario-planning workshop in January 2017 with 21 participants from the Partnership. Prior to the workshop, participants were provided with a variety of publicly available, internet-based resources describing climate change effects, population growth, and social vulnerability (Appendix 1).
Participants individually identified ecological goods and services of value to help focus the development of alternative scenarios (Keeney 1992). A shorter list of values was subsequently constructed based on the frequency with which various goods and services were mentioned. The idea was to aid scenario planning by underscoring what values were at risk in a set of plausible futures. Scenarios were developed for so-called "tailored exploration," in which a participatory process is used to identify key drivers and trends that will shape the future of ecological goods and services in the Lowcountry through the year 2050 (Wiseman et al. 2011). We used the "intuitive logics scenario process" or "driving forces method," which addresses an external environment largely beyond the control of the decision maker (Wright et al. 2013). Strategic actions are evaluated against the resulting scenarios and, as such, actions are not considered part of the scenarios themselves.

Workshop participants relied on social, technological, environmental, economic, and political (STEEP) indicators to help identify important drivers of ecological goods and services (Rounsevell and Metzger 2010, Wiseman et al. 2011, National Park Service 2013). Drivers were considered in terms of degree of impact and degree of uncertainty (Wiseman et al. 2011, Wright et al. 2013, Goodwin and Wright 2014). Participants assessed and prioritized drivers, recognizing the importance of governance (Berkhout et al. 2002, Tompkins et al. 2008) at multiple scales (Rounsevell and Metzger 2010, Sheppard et al. 2011), as well as how perceptions are mediated by culture (Ney and Thompson 2000, Crane 2010, Cobb and Thompson 2012, Adger et al. 2013). We identified three principal drivers and created four alternative scenarios. Scenarios were used in a follow-up workshop to help develop strategic actions to help mitigate the effects of global change.

\section{Strengths, weaknesses, opportunities, and threats (SWOT) analysis}

Strengths, weaknesses, opportunities, and threats (SWOT) is a tool developed for situational awareness and strategic planning (Weihrich 1982). It is used to examine an organization's internal strengths and weaknesses, and to evaluate external threats and opportunities, to help formulate effective business strategies. It is a simple and practical tool for rapid assessment that can provide insights into the complex interplay of factors affecting an organization's success (Pickton and Wright 1998, Helms and Nixon 2010, Nyarku and Agyapong 2011). The SWOT tool has been used extensively in the business world (Helms and Nixon 2010) and has seen growing use in natural resource management (Hong and Chan 2010, Kajanus et al. 2012, Siaosi et al. 2012, Marino et al. 2014, Haryono and Ambariyanto 2017), although its use in the context of climate-change adaptation appears more limited (Krysanova et al. 2010, Fertel et al. 2013).

We held a second workshop to conduct a SWOT analysis in November 2018 with many of the same participants from the scenario-planning workshop. We generally followed the process described by Weihrich (1982), which is regarded as the most important methodological reference (Ghazinoory et al. 2011) in that it seeks to make SWOT analyses more applicable for generating effective strategies (Helms and Nixon 2010). Prior to the workshop, participants were provided background material about SWOT analyses and requested to think about specific 
strengths and weaknesses of their respective organizations, with a focus on addressing the current and future conditions, opportunities, needs, and threats facing the Lowcountry as described by the previously created scenarios. At the workshop, individuals listed their organization's strengths and weaknesses on notes, which were color-coded to distinguish among federal, state, and NGO partners. These factors were placed on flip charts, grouped thematically, and similar items were combined. Colorcoding allowed us to understand how capabilities and perspectives might differ among organizations. In a plenary meeting, the articulated strengths and weaknesses were discussed and the top four to six were identified by consensus for consideration by the conservation Partnership as a whole. For example, an organization's weakness may have been dropped from the list if it was negated by another organization's strength. The idea is analogous to that in ecological systems, in which functional redundancy and diversity can promote resilience (Norberg et al. 2008). The goal was to emphasize the importance of collaboration and the collective capabilities of the Partnership.

Because of time constraints, participants focused largely on one of the four scenarios considered most plausible and discussed and developed a list of the most important threats and opportunities. Participants then individually ranked and scored ( 0 to 100 , with 100 being the most important) the strengths, weaknesses, threats, and opportunities on a handout provided.

Each pairwise combination of internal and external SWOT factors was then examined, and one or more Partnership strategies developed using a so-called TOWS matrix (simply a reverse ordering of SWOT intended to emphasize the importance of external threats and opportunities of the scenarios; Weihrich 1982). For each strategy, participants recorded which pairs of SWOT factors the strategy was intended to address. After the workshop, we used the mean of the participants' scores for the individual SWOT factors and summed those scores for the specific pairs of SWOT factors associated with each strategy. This provided a crude measure of the relative importance of each strategy. This enumeration was done to help address a common criticism of SWOT that it does not assist decision makers with prioritization (Helms and Nixon 2010, Nyarku and Agyapong 2011).

\section{RESULTS}

\section{Stakeholder identification}

Workshop participants identified a large and diverse group of Lowcountry stakeholders that could be engaged more proactively to help the region adapt to the forces of change. Recognizing the potential for a diversity of agency helped illuminate the extent of stakeholders' interest in, and knowledge of, the changes in the region, as well as their capacity to influence the nature of adaptation. Although dozens of stakeholder groups were identified, we broadly categorized them as falling within nine general groups (Fig. 3). Many were perceived as having a high interest in the changes being experienced by the region, but their perceived power to affect the course of adaptation varied widely. For example, the region relies heavily on ecotourism, yet ecotourists as a group were understood to wield little power in the governance of the region. Agricultural interests, on the other hand, were perceived as both extremely interested and empowered to influence the future of the Lowcountry. Given the extent to which the interests of agriculture and conservation overlap (Scherr and McNeely 2008), more proactive engagement of the farming and timber industries may provide a straightforward and effective way to broaden the Partnership's message and influence.

Fig. 3. Major stakeholder groups and their perceived level of interest and power as identified by the Cape Romain Partnership for Coastal Protection.

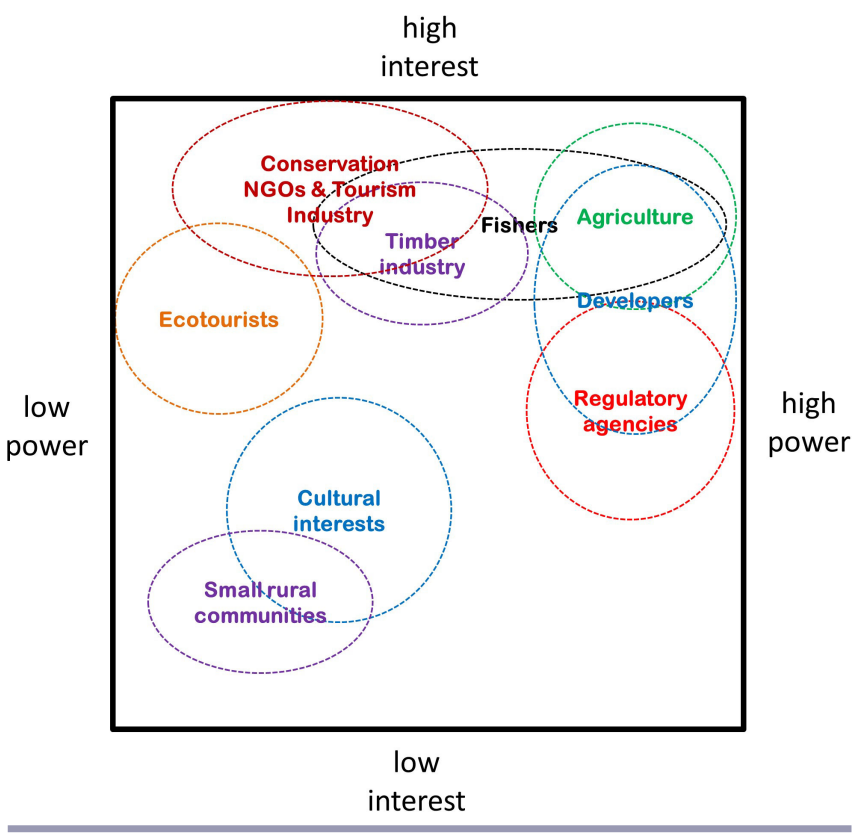

\section{Scenario planning}

A large array of ecological goods and services of value were identified by workshop participants (Table 1). Based on the frequency with which they were mentioned, cultural values and provisioning services seem to be of greatest concern. Even among conservation interests, cultural values and provisioning services tended to be mentioned more than traditional conservation values such as biodiversity.

Several potential drivers of change in the Lowcountry were identified by workshop participants. All were considered of high impact. Sea-level rise and population growth were considered the most certain, whereas economic opportunity, climate variability, and politics were considered the least certain. We identified three principal drivers that encapsulated the most relevant and diverse drivers identified at the workshop:

(1) Climate change: The severity of climate change was considered a major driver and was the easiest driver to define. It included all specifics of climate change (e.g., sea-level rise, frequency of extreme weather events, etc.).

(2) Changing world order: Much of the workshop discussion was underscored by a theme of national and global social-political shifts and upheaval. Recognizing that such global-scale changes can have important implications at the local level, we struggled with how to capture this complexity. How the U.S. responds to ongoing trends in globalization will influence the state and direction of the national economy, immigration patterns, political polarization, and cultural identity. The feeling that these features 
are changing in (unpredictable) ways that exclude certain segments of the population, empower others, and exacerbate environmental degradation was discussed at length during the workshop. Because such social-political shifts were described as major drivers of change at a local level, we tried to capture their root cause as an uncertain but primary driver.

(3) Local values and power structures: The local/regional cultural milieu and social systems were perceived as key areas in which major drivers could be mitigated or exacerbated. This driver tries to capture the idea of social resilience, how forces such as identity unite or divide individuals and communities, how individuals and communities mobilize resources, and how they are organized by some form of institutionalized hierarchy (power structures).

Table 1. Summary of ecological goods and services of value identified by participants of the Cape Romain Partnership for Coastal Protection.

\begin{tabular}{|c|c|}
\hline $\begin{array}{l}\text { Type of ecological good or } \\
\text { service }\end{array}$ & Specific good or service \\
\hline Cultural values & $\begin{array}{l}\text { Quality of life: psychological well-being, } \\
\text { aesthetics, place attachment and identity, } \\
\text { religious/spiritual value } \\
\text { Cultural heritage: Gullah culture, sweetgrass, } \\
\text { archeological sites } \\
\text { Outdoor recreation: fishing, hunting, } \\
\text { ecotourism }\end{array}$ \\
\hline Provisioning services & $\begin{array}{l}\text { Marine: fish, shrimp, oysters, blue crabs, } \\
\text { horseshoe crabs } \\
\text { Timber } \\
\text { Game animals }\end{array}$ \\
\hline Biodiversity & $\begin{array}{l}\text { Threatened and endangered species: sea } \\
\text { turtles, red-cockaded woodpecker } \\
\text { Migratory birds, especially shorebirds } \\
\text { Wildlife habitat quality/quantity/connectivity }\end{array}$ \\
\hline Regulating services & $\begin{array}{l}\text { Disturbance abatement: due to storm surge, } \\
\text { flooding, erosion } \\
\text { Water quality and quantity: as affected by } \\
\text { runoff/pollution, salinity, aquifer recharge } \\
\text { Air quality: carbon sequestration }\end{array}$ \\
\hline
\end{tabular}

All scenarios assumed population growth will continue at pace through 2050. Participants agreed that there was little uncertainty about future population growth trends (http://www.sccommunityprofiles. org/census/proj_c2010.html). How this influx of people affects the area, both in terms of infrastructure and societal reaction, will depend on other drivers at the local and regional scale.

Prior to articulating scenarios, we characterized the nature of moderate and severe changes that might be expected for the three principal drivers of change (Tables 2, 3, 4). For climate change, characterizations were based largely on observed trends and forecasts for the Lowcountry (Appendix 1). Characterizations of a changing world order and local values and power structures were modeled on literature-based, theoretical arguments (Harrison and Burgess 1994, Ney and Thompson 2000, Lambin et al. 2001, Demeritt 2002, Frank 2016, Gardels and Berggruen 2017). Using combinations of moderate and severe changes for the three principal drivers, four scenarios were created depicting two extreme and two intermediate futures. The scenarios are somewhat lengthy narratives and thus have not been reproduced here, but are available in Appendix 2.
Table 2. Characterizations of moderate and severe climate change used to develop alternative future scenarios for the Lowcountry of South Carolina. Note: SLR = sea-level rise.

\begin{tabular}{|c|c|}
\hline Moderate & Severe \\
\hline $\begin{array}{l}\text { - SLR of } \leq 1 \text { foot by midcentury; } \\
\text { - > } 180 \text { tidal floods per year in } \\
\text { Charleston; } \\
\text { - No change in average } \\
\text { precipitation, but moderately } \\
\text { increased frequency of extreme } \\
\text { events (drought, rain bombs, } \\
\text { tornadoes); } \\
\text { - Average annual temperature } \\
\text { increase will be moderate, slightly } \\
\text { increasing competition for } \\
\text { freshwater; } \\
\text { - Only minimal changes in } \\
\text { seawater pollution, temperature, } \\
\text { acidity, and salinity; } \\
\text { - Frequency of tropical storms } \\
\text { continues at historic rate of about } \\
\text { one landfall every three years, with } \\
\text { most storms being category } 1 \text { or } \\
\text { less; even with more moderate } \\
\text { SLR, this increases the potential } \\
\text { for widespread damage from } \\
\text { storm surge. }\end{array}$ & $\begin{array}{l}\text { - SLR of } 2 \text { feet by midcentury; } \\
\text { - > } 270 \text { tidal floods per year in } \\
\text { Charleston; } \\
\text { - Slight increase in average } \\
\text { precipitation, but greatly increased } \\
\text { frequency of extreme events } \\
\text { (drought, rain bombs, tornadoes); } \\
\text { - Average annual temperature will } \\
\text { increase } 3-4{ }^{\circ} \mathrm{F} \text {, increasing the } \\
\text { frequency and severity of heat } \\
\text { waves and competition for } \\
\text { freshwater; } \\
\text { - Significant increase in seawater } \\
\text { pollution, temperature, acidity, and } \\
\text { salinity; } \\
\text { - Frequency of tropical storms } \\
\text { continues at historic rate of about } \\
\text { one landfall every three years, but } \\
\text { more storms will be category } 2 \text { and } \\
\text { higher; with high SLR, this } \\
\text { increases the potential for } \\
\text { catastrophic storm surge. }\end{array}$ \\
\hline
\end{tabular}

\section{Strengths, weaknesses, opportunities, and threats (SWOT) analysis}

Organizational strengths of the Partnership included the capacity to build productive networks and collaborations, legal authorities, public support, natural resource expertise, resources (especially the conservation land base), and outreach capacity. Weaknesses included communication and marketing, internal alignment (i.e., consistent goals and priorities within an organization), institutional inertia, limited funding and staff, and shifting political priorities. Generally, federal partners indicated they have legal authorities for conservation and the capacity to develop strong conservation partnerships, but they struggle with limited funding and institutional inertia. State agencies were not wellrepresented at the second workshop, but based on their input during other activities, we interpreted their strengths and weaknesses to be similar to those of the federal partners. The NGOs indicated they have strong outreach capacity and natural resource expertise, but they have limited staff and lack expertise in marketing.

The primary external threats were: unchecked population growth and associated development, impacts to human health and wellbeing, and extreme weather impacts to ecological goods and services (EGS) of value. The most important opportunities were an attractive culture and lifestyle in the Lowcountry (social cohesion), a high demand for EGS, and opportunities for partnerships.

Potential strategies were developed for each pairwise combination of strengths/weaknesses and threats/opportunities (Fig. 4). Virtually all strategies involved stakeholder engagement, outreach, and development of partnerships. Strategies with the highest scores were: (1) communicate benefits of existing 
protected areas in providing ecological goods and services; (2) increase conservation community self-awareness (expand partnerships and connect expertise with when, where, how it is needed); and (3) conduct outreach in a way that connects quality of life, culture, and demand for EGS with conservation.

Table 3. Characterizations of moderate and severe changing world order used to develop alternative future scenarios for the Lowcountry of South Carolina.

\begin{tabular}{|c|c|}
\hline Moderate & evere \\
\hline $\begin{array}{l}\text { - A responsible nationalism } \\
\text { emerges (i.e., the U.S. desires to } \\
\text { maximize the welfare of its } \\
\text { citizens, but within a global } \\
\text { community of interests); America } \\
\text { takes strong leadership role in } \\
\text { global response and directions, } \\
\text { including economic, social } \\
\text { equality, and environment; } \\
\text { - Nations increase societal safety } \\
\text { nets and access to lifelong learning } \\
\text { to combat the downsides of } \\
\text { globalization, fostering rapid } \\
\text { growth of entrepreneurship in } \\
\text { information/internet technology in } \\
\text { which more can participate in an } \\
\text { expanding economy; } \\
\text { - Effective institutions of global } \\
\text { governance emerge, as the world's } \\
\text { largest economies (particularly } \\
\text { China, India, and America) find } \\
\text { ways to work together; } \\
\text { - Equitable trade policies are } \\
\text { negotiated, increasing economic } \\
\text { stability and sustaining growth; } \\
\text { - People feel more empowered as } \\
\text { democracy and other participatory } \\
\text { forms of governance expand; } \\
\text { - A greater sense of empowerment } \\
\text { leads to more trust in institutions } \\
\text { and the media, and this helps } \\
\text { moderate the social, economic, and } \\
\text { political upheaval associated with } \\
\text { unchecked globalization ; } \\
\text { - An effective global governance } \\
\text { promotes sustainability, moderates } \\
\text { the severity of climate change, } \\
\text { keeps national and corporate } \\
\text { power in check, and reduces the } \\
\text { chance of regional conflict. }\end{array}$ & $\begin{array}{l}\text { - Global backlash to globalization } \\
\text { deepens and spreads, accompanied } \\
\text { by rise of nationalism, } \\
\text { authoritarianism, and government } \\
\text { corruption; } \\
\text { - Shifting power relationships fosters } \\
\text { continued breakup of traditional } \\
\text { alliances, leading to new geopolitical } \\
\text { spheres of influence, which in turn } \\
\text { fosters higher potential for regional } \\
\text { wars, refugee crises, and nuclear } \\
\text { proliferation; } \\
\text { - Distrust of governments, } \\
\text { institutions, and the media deepens; } \\
\text { - Xenophobia, intolerance, and } \\
\text { religious fundamentalism deepen } \\
\text { and spread as cultures struggle to } \\
\text { cope with social, economic, and } \\
\text { political upheaval; } \\
\text { - Possibility of trade wars among } \\
\text { economic powers increases; } \\
\text { - Global corporations exert growing } \\
\text { power because of the vacuum in } \\
\text { global governance; this fosters rapid } \\
\text { growth in mostly carbon heavy } \\
\text { sectors and the military-industrial } \\
\text { complex; } \\
\text { - Global cooperation on combating } \\
\text { climate change languishes as more } \\
\text { authoritarian-style leadership } \\
\text { focuses on quick solutions to local } \\
\text { problems; environmental regulations } \\
\text { are weakened. }\end{array}$ \\
\hline
\end{tabular}

\section{DISCUSSION}

Based on our experiences, we present several considerations for engaging individuals and organizations interested in adapting to the uncertain future of the Lowcountry (Fig. 2). We believe these findings and ideas will also have applications to other places confronting complex environmental problems and uncertain futures. Our thoughts comport with the emerging view that practical solutions to wicked problems will ultimately be generated by local actors behaving in accordance with their own particular perception of the social-ecological landscape (Rayner and Malone 1997, Verweij et al. 2006, Crane 2010). This is a fundamentally different perspective from that in much of resource and ecosystem management, which tend to be positivistic, strategic, and hierarchical (Berkes 2010).

Table 4. Characterizations of moderate and severe local values and power structures used to develop alternative future scenarios for the Lowcountry of South Carolina.

\begin{tabular}{|c|c|}
\hline Moderate & Severe \\
\hline $\begin{array}{l}\text { - Focus is more on community- } \\
\text { based values, with more emphasis } \\
\text { on maintaining social and } \\
\text { economic regulations and safety } \\
\text { nets; } \\
\text { - Place-based values and identity } \\
\text { enhance social cohesion even with } \\
\text { continued immigration, resulting in } \\
\text { more power sharing, participatory } \\
\text { forms of local governance, and } \\
\text { government accountability; } \\
\text { - Social and environmental values } \\
\text { are of high priority, with emphasis } \\
\text { on egalitarianism, and community } \\
\text { and incentive-based solutions; } \\
\text { - Society is buffered against the } \\
\text { worst impacts of global change } \\
\text { because of strong emphasis on } \\
\text { education and community-based, } \\
\text { proactive planning (e.g., smart } \\
\text { growth). }\end{array}$ & $\begin{array}{l}\text { - Focus is on individual-based } \\
\text { values, with limited regulations on } \\
\text { social and economic policies; } \\
\text { - Historic tradition of paternalistic } \\
\text { politics in the Lowcountry endures, } \\
\text { in which those who hold power are } \\
\text { rarely challenged; this leads to a } \\
\text { high potential for political } \\
\text { corruption; } \\
\text { - Large-scale forces and private } \\
\text { industry exert a strong influence on } \\
\text { local social, economic, and } \\
\text { environmental policy; private } \\
\text { interests are pursued at the expense } \\
\text { of cultural heritage and social } \\
\text { cohesion; focus is on economic } \\
\text { growth; } \\
\text { - Public services and income equality } \\
\text { decline, and immigration and } \\
\text { unchecked development make some } \\
\text { population segments even more } \\
\text { vulnerable to global change; } \\
\text { - Resiliency to even moderate } \\
\text { climate change declines because } \\
\text { largely regulation-based corrective } \\
\text { measures are slow to be } \\
\text { implemented. }\end{array}$ \\
\hline
\end{tabular}

We suggest that place-based experiences and power differentials can help shape stakeholder engagement strategies, because groups that operate at levels that are further removed from the immediate landscape of the Lowcountry (e.g., national-level organizations such as large conservation groups or governmental organizations) are engaged in ways that are different from those groups that operate primarily within the confines of the local landscape (e.g., local municipalities, churches, small businesses, and homeowners). Although phone calls with individuals that represent national or state level government organizations would be appropriate, conversations with locally focused organizations perhaps should be conducted in face-to-face settings. These differences in operational level also often relate to power differentials, i.e., groups that have funding and support of the federal government likely have greater power than hyper-local organizations. We recommend adopting a stages of change approach from behavior theory to understand such differentials among divergent stakeholder groups and to address root factors that may influence motivations and actions at different stages of engagement and adaptation processes. Such change theory models have been used for a variety of applications including addressing behavioral health and problems associated with climate and environmental change (e.g., Nisbet and Gick 2008, Semenza et al. 2008, Armitage 2009).

Welcoming a divergence of stakeholder perspectives (be they knowledge, attitudinal, cultural, or otherwise) enhances the 
Fig. 4. Example of SWOT analysis, representing primary strengths, weaknesses, opportunities, and threats, and identifying potential strategies for the Cape Romain Partnership for Coastal Protection. Note: EGS refers to ecological goods and services.

\begin{tabular}{|c|c|c|}
\hline & \\
\hline & External Opportunities & External Threats \\
\hline & $\begin{array}{l}\text { 1. Culture/lifestyle is attractive (social } \\
\text { cohesion) } \\
\text { 2. High demand for EGS } \\
\text { 3. Opportunities for partnerships }\end{array}$ & $\begin{array}{l}\text { 1. Unchecked growth and development } \\
\text { 2. Impacts to human health and well- } \\
\text { being } \\
\text { 3. Extreme weather impacts to EGS }\end{array}$ \\
\hline $\begin{array}{l}\text { 1. Outreach capacity } \\
\text { 2. Expertise in natural resource } \\
\text { management } \\
\text { 3. Partnership experience \& competence } \\
\text { 4. Existing land base }\end{array}$ & \multirow[t]{2}{*}{$\begin{array}{l}\text { Outreach in a way that connects quality of } \\
\text { life, culture, and demand for EGS with } \\
\text { conservation } \\
\text { Increase conservation community self- } \\
\text { awareness (expand partnerships and } \\
\text { connect expertise when, where, how it's } \\
\text { needed) } \\
\text { - Protect and expand conservation lands } \\
\text { through partnerships }\end{array}$} & \multirow[t]{2}{*}{$\begin{array}{l}\text { - Communicate benefits of existing } \\
\text { protected areas in providing EGS } \\
\text { - Guide growth and land protection based } \\
\text { on existing land base using partnerships } \\
\text { \& diverse funding }\end{array}$} \\
\hline Partnership Weaknesses & & \\
\hline $\begin{array}{l}\text { 1. Expertise in messaging/marketing } \\
\text { 2. Funding \& capacity limitations } \\
\text { 3. Institutional inertia } \\
\text { 4. Internal alignment }\end{array}$ & $\begin{array}{l}\text { - Capitalize on EGS demand and outreach } \\
\text { and partnership expertise to increase } \\
\text { internal alignment and support } \\
\text { - Expand and diversify partnerships to } \\
\text { address funding limitations } \\
\text { - Target partnership development to } \\
\text { improve marketing and fund-raising }\end{array}$ & $\begin{array}{l}\text { Explore and develop mitigation funding } \\
\text { mechanisms } \\
\text { - Develop and communicate the benefits of } \\
\text { zoning regulations and smart-growth } \\
\text { planning } \\
\text { - Partner with health organizations to } \\
\text { connect conservation with human health } \\
\text { benefits } \\
\text { - Market health and weather impacts to } \\
\text { help address internal alignment, inertia, } \\
\text { and funding }\end{array}$ \\
\hline
\end{tabular}

ability to coproduce shared understanding and actionable solutions to problems in conservation and resource management. Our current perception of coproduction is that of a normative approach, in which experts and users collaborate to develop a shared body of knowledge (Mitchell et al. 2004). In this view, scientists work with stakeholders to help frame questions, script research, and collect and analyze data (Klenk et al. 2015). Such sustained collaborations are increasingly believed to be an effective way to produce useable (or actionable) science (Meadow et al. 2015). When these collaborations are combined with a community-of-inquiry approach to learning (Ison 2010, Haynes 2018), knowledge and sense-making unfold through complex interactions of social, cognitive, and teaching elements (Swan and Ice 2010). This approach differs dramatically from engagement activities that envision learning as a unidirectional, teacher-tostudent process. Irrespective of any specific view of coproduction is the belief that allowing participants to interpret information in a way that resonates more clearly with their lived experiences, while enabling them to empathize with competing perspectives, can help overcome the science-policy gap in climate-change adaptation (Schuttenberg and Guth 2015). Key to any coproduction approach is the involvement of social scientists, who can analyze social interactions in a given decision context, and inform the development of participatory scientific inquiry and collective decision making (Weaver et al. 2014).
Successful coproduction can be quite difficult, however, because of differences between experts and stakeholders in their perception of timeframes, reward structures, goals, process cycles, and epistemologies (Hegger and Dieperink 2014). The challenge is to facilitate a shift from disparate, self-focused perspectives of a problem to a holistic, collective framework for knowledge production, in which stakeholders are given an equal voice so that trust, creativity, and a shared perspective can develop (Schuttenberg and Guth 2015). Boundary organizations (or individuals) are seen as an effective way to enable this social learning, in which science is viewed within the context of values and political processes (Bidwell et al. 2013, Hegger and Dieperink 2014). Socially focused conservation organizations can serve both as a bridging organization and a facilitator of boundary networks, in which dynamic problems can be addressed through changing communities of decision makers and scientists (Bidwell et al. 2013). Employing a stages-of-behavior-change model to evaluate interest levels, preparedness for action, and other phases of behavior modification, is likely to be a worthwhile consideration for any coproduction process.

Scenario planning can be a useful tool for coproduction and an effective tactic for coping with wicked problems (Peterson et al. 2003, Camillus 2008). A participatory approach to scenario planning can provide saliency, credibility, and legitimacy to future storylines, as well as a vehicle for consensus building and problem 
solving (Rounsevell and Metzger 2010). Scenario planning acts to promote social learning by fostering greater awareness of social-ecological change and its impacts, by exploring and integrating many different issues and forms of knowledge, by exposing and exploring different worldviews, and by encouraging greater awareness of the role of human choices and actions in shaping the future (Wiseman et al. 2011). Our scenario-planning exercise helped highlight the importance of scale in adaptation to social-ecological change, whereby planners must attempt to understand the spatial and temporal scales of ecological goods and services, the ecological scales involved in their production, and the institutional scales at which they are managed (Adger et al. 2005b, Hein et al. 2006, Paloniemi et al. 2012). The scenarios also emphasized how political and economic trends in far reaches of the globe can have an impact on local adaptation planning (Lambin et al. 2001, Lambin and Meyfroidt 2011, Meyfroidt et al. 2013).

Scenario planning does have its limitations, however. As in other cases, our workshop lacked diversity in participants (most were part of the conservation community), and the limited perspectives could weaken scenario credibility when communicating storylines and strategy outcomes to more diverse groups (Rounsevell and Metzger 2010). We were subject to other common pitfalls as well, including insufficient time for scenario development, unrealistic goals and expectations of the process and products, and a lack of a clear link between scenarios and the planning processes (Duinker and Greig 2007). Indeed, how scenarios may be better used to catalyze institutional and behavioral change remains somewhat of an open question (Rosentrater 2010). For this reason, there has been increasing interest in combining scenario planning with other tools of multicriteria decision analysis (Montibeller et al. 2006, Karvetski et al. 2011). We attempted to address this limitation by incorporating scenario planning with a semiquantitative ranking of adaptation strategies using the SWOT and TOWS frameworks.

Implications of panarchy theory were also apparent in our engagement with the Partnership. Recognition of multiple scales of influence was a dominant motif in our scenario-planning exercises, in which local cultural differences, national politics, and globalization shaped discussions about the region's future. The conservation community in the Lowcountry also has shown a long-term pattern of punctuated equilibrium, in which relatively long periods of stability were interrupted by periods of innovation and change (Halfacre 2013). For example, Hurricane Hugo, a category 4 storm making landfall at Cape Romain National Wildlife Refuge in 1989 caused billions of dollars in damage and 35 fatalities. However, this catastrophic event provided an opportunity for local leaders to reflect and act upon the effect of rampant growth and development on the region's quality of life (Halfacre 2013).

Through our interactions with the Partnership, it became apparent that the conservation community is integral to the broader governance of the Lowcountry's social-ecological system, in which responses to the forces of global change are mediated through local culture, economics, and politics. For example, there is a growing interest in environmental justice in the conservation movement, in which the focus turns to how wealth, opportunities, and privileges are distributed within society (Brechin et al. 2002, Martin et al. 2013, Shoreman-Ouimet and Kopnina 2015). This implies an interpretation of conservation in which the fundamental objectives of both social and ecological systems are prioritized in tandem, rather than narrowly focusing on environmental protection without consideration of the social landscape (Biedenweg and GrossCamp 2018). The Partnership supported this approach by identifying the rich cultural heritage, attractive Lowcountry lifestyle, and high demand for EGS as important opportunities for conservation. This perspective places a high value on social cohesion (Stanley 2003) as integral to the future of the landscape.

Adaptive capacity is defined as the ability to prepare for environmental stressors in advance, or to adjust and respond to stressor effects (Engle 2011). The greater the adaptive capacity, the greater the resilience to disturbances like sea-level rise, tropical storms, economic downturns, and other sources of social disruption. We believe one key to the process of building adaptive capacity is to consider lessons from human behavior theory and models to better understand stakeholder agency, perceptions, and preparedness for engagement and taking action. People live their daily lives in a sea of meaning, in which there are power relations and individual and group identities not necessarily evident to those seeking engagement. Application of such theory encourages an appreciation of the diverse ways in which people and organizations perceive the social-ecological systems in which they are embedded, and in so doing can facilitate more effective engagement and communication strategies (Armitage 2009). By recognizing these distinctions, conservation practitioners can design effective messages and activities that better align with what is most appropriate for a specific area, issue, and audience. Traditional engagement and communication often start with the notion that stakeholders simply need more information to make appropriate decisions, sometimes resulting in a surplus of information and a dearth of action (Kollmuss and Agyeman 2002, Cox 2012).

Our stakeholder engagement in this project, however, was limited to a relatively small representation of the broader conservation community, and many participants were most interested in identifying concrete actions to address changes being experienced in the Lowcountry. When such actors have well-developed concerns for impending threats and are already prepared to act, scenario-planning exercises may not resonate strongly, because these individuals are likely to feel that a focused discussion on specific actions is more relevant. Our experience demonstrated, however, that scenario-planning exercises can reveal unexpected avenues through which the conservation community could pursue its goals. Moreover, envisioning alternative futures can be useful to help broader, more diverse stakeholders develop a shared perspective of the changes and associated challenges confronting the Lowcountry. As engagement expands to include a greater diversity of perspectives, planners and researchers should be prepared to understand and address how differing priorities and values may influence engagement efforts.

Adaptive capacity ultimately depends on the ability to act collectively, and social capital, trust, and organization greatly influence the capacity to act (Adger 2003). The presence of strong social networks, coordination and deliberation among diverse stakeholders, mechanisms for experiential feedback (e.g., 
adaptive management), and emphasis on social learning are key elements contributing to adaptive capacity (Dietz et al. 2003, Olsson 2004, Pahl-Wostl 2009). In a sense, the Lowcountry, as a place, functions as one of many actors which, operating within a network of relationships, prompt, enable, or constrain action, thereby influencing conservation outcomes (Jepson et al. 2011). Simon Levin (1999:38) observed: "as systems develop, networks of interactions develop for a variety of reasons, some simply have to do with chance and geography, others having to do with choice and calculation."

Our goal was to assist the conservation and other Lowcountry communities make informed and calculated choices in guiding the formation of capable, resilient networks rather than leaving this development to chance. The Partnership has taken important steps toward building adaptive capacity by networking with various conservation interests and by exploring the coproduction of knowledge and meaning. By assessing strengths and weaknesses of its constituent members, the Partnership has begun to understand the extent of diversity and redundancy, essential features of adaptive capacity, within the conservation community (Gunderson and Holling 2002). For example, government partners indicated they have legal authorities for conservation and suitable capacity to develop conservation partnerships, but they struggle with limited funding and institutional inertia. Private organizations indicated they have strong outreach capacity and natural resource expertise, but they have limited staff and lack expertise in marketing. Thus, the Partnership is seeking to expand and diversify its membership to help address funding limitations and to better provide decision support when and where it is needed. Finally, we recognize our efforts represent only an early phase of efforts to build greater adaptive capacity in the Lowcountry. But by coproducing plausible future scenarios, understanding the weaknesses and strengths of individual conservation groups, and by identifying a wide range of stakeholder perspectives, levels of interest, and influence, the Partnership is now better prepared to engage a broader, more diverse social landscape.

\section{CONCLUSIONS}

Our involvement in this project was at the behest of coastal National Wildlife Refuges, which have a keen interest in the protection and management of fish and wildlife habitats to offset those lost to sea-level rise. We sought to develop prioritization tools to support this goal (e.g., Eaton et al. 2019), but our efforts ultimately focused more on engagement of other conservation interests and collective decision making within the larger socialecological system that is the Lowcountry. This focus on process over product differs from the strategic guidance provided by the refuge system, which emphasizes training employees in climatechange adaptation, providing technical assistance (U.S. Fish and Wildlife Service 2010), educating the public about climate change, protecting infrastructure, and using energy wisely (Czech et al. 2014). Strategic guidance from scholars is likewise very much refuge centric (Griffith et al. 2009, Iguchi 2011, Magness et al. 2012). However, even when refuge decision makers are clear about the systemic and individual refuge objectives they wish to pursue (Iguchi 2011), they must consider tradeoffs and actions required, involving multiple levels of governance, from local stakeholders to regional institutions and national politics. The view of this governance landscape will vary widely among refuges (Gunderson and Holling 2002), sometimes engendering feelings of isolation, hopelessness, and despair in facing the local impacts of large-scale climate change and other stressors (Bryant et al. 2012; Fig. 5).

Fig. 5. A refuge biologist surveys the effect of sea-level rise at the "boneyard" on Cape Romain National Wildlife Refuge in South Carolina (photo credit: F. A. Johnson).

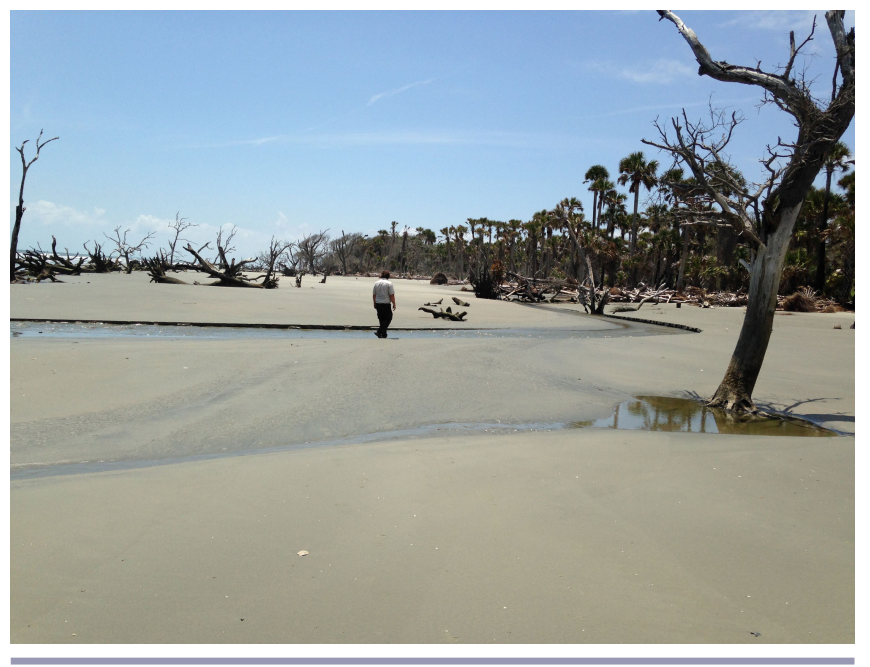

We believe this sense of isolation can be overcome in part by engaging local conservation interests and, perhaps more importantly, those who depend on the ecological goods and services that support quality of life. This is likely to be unfamiliar territory for refuge staff, whose principal focus is on maintaining routine refuge operations and trying to mitigate or adapt to impacts of climate change on the refuge itself (Johnson et al. 2015). Fortunately for Cape Romain National Wildlife Refuge, there is a diverse, active, and vibrant conservation community in the Lowcountry (Halfacre 2013). Opportunities for engagement abound and, if seized upon, can minimize the problem of fit and enhance the capacity for collective action.

Central to an evolving perspective of governance of the commons (Dietz et al. 2003) is the recognition that social and ecological systems are coupled; the issues and problems of one cannot be addressed without considering the consequences for the other. Moreover, a dominant theme emerging from our research and that of other scholars is the importance of place attachment, which generates social cohesion and facilitates problem solving. These ideas have important implications for when, where, and how stakeholders are engaged to address changes being experienced by social-ecological systems.

Cultural construction, a central tenet of anthropology, sociology, and cultural geography, suggests that how we view, understand, and experience the world can vary greatly among individuals (Demeritt 2002, Crane 2010). These are not trivial differences a linear process of decision making can overcome. In the end, complex environmental problems can only be solved by society at large; therefore, acceptable solutions will only arise when there is a respect for the pluralities of experience and meaning that stakeholders bring with them to the decision-making process. Plurality then is not merely a nuisance to be abstracted away, but something that must be embraced in any attempt to solve a wicked problem. 
Responses to this article can be read online at:

http://www.ecologyandsociety.org/issues/responses. $\mathrm{php/11700}$

\section{Acknowledgments:}

Funding for this research was provided by the U.S. Geological Survey, Southeast Climate Adaptation Science Center. We thank those who contributed to early project framing and design, including S. Baird, M. Bryant, J. Constanza, S. Dawsey, B. van Druten, S. Lanier, J. Martin, J. McMahon, R. Nilius, E. Pienaar, N. Pau, M. Ratnaswamy, S. Romanach, S. Seibert, L. Taylor, B. Udell, P. Wingrove, and N. Wood. We also acknowledge the contributions and dedication of Coastal Conservation Partnership members including J. Brown, G. Budds, S. Dawsey, C. Fleming, E. Fly, M. Gorstein, L. Hayden, V. Keeler, E. Krueger, S. Lovelace, A. Margiotta, F. Mauney, M. Morrison, P. Nadler, B. Perry, W. Peters, S. Regan, L. Shealy, A. Smith, K. Thorvalson, E. Tupacz, N. Rankin, J. White, and M. Whitehead. We appreciate helpful reviews of earlier manuscript drafts by G. McMahon, C. Maller, and three anonymous reviewers. Any use of trade, firm, or product names is for descriptive purposes only and does not imply endorsement by the U.S. Government.

\section{Data Availability Statement:}

Data and other information originating from this study have not been made publicly available. Readers interested in more information are encouraged to contact the corresponding author.

\section{LITERATURE CITED}

Adger, W. N. 2003. Social capital, collective action, and adaptation to climate change. Economic Geography 79 (4):387-404.

Adger, W. N., N. W. Arnell, and E. L. Tompkins. 2005b. Successful adaptation to climate change across scales. Global Environmental Change 15(2):77-86. https://doi.org/10.1016/j.gloenvcha.2004.12.005

Adger, W. N., J. Barnett, K. Brown, N. Marshall, and K. O’Brien. 2013. Cultural dimensions of climate change impacts and adaptation. Nature Climate Change 3:112-117. https://doi. org/10.1038/nclimate1666

Adger, W. N., S. Dessai, M. Goulden, M. Hulme, I. Lorenzoni, D. R. Nelson, L. O. Naess, J. Wolf, and A. Wreford. 2009. Are there social limits to adaptation to climate change? Climatic Change 93(3):335-354. https://doi.org/10.1007/s10584-008-9520$\underline{\mathrm{Z}}$

Adger, W. N., T. P. Hughes, C. Folke, S. R. Carpenter, and J. Rockström. 2005a. Social-ecological resilience to coastal disasters. Science 309(5737):1036-1039. https://doi.org/10.1126/ science. 1112122

Ajzen, I. 2002. Perceived behavioral control, self-efficacy, locus of control, and the theory of planned behavior. Journal of Applied Social Psychology 32(4):665-683. https://doi.org/10.1111/j.1559-1816.2002. tb00236.x
Arkema, K. K., G. Guannel, G. Verutes, S. A. Wood, A. Guerry, M. Ruckelshaus, P. Kareiva, M. Lacayo, and J. M. Silver. 2013. Coastal habitats shield people and property from sea-level rise and storms. Nature Climate Change 3(10):913-918. https://doi. org/10.1038/nclimate1944

Armitage, C. J. 2009. Is there utility in the transtheoretical model? British Journal of Health Psychology 14(2):195-210. http://doi. org/10.1348/135910708X368991

Berkes, F. 2010. Shifting perspectives on resource management: resilience and reconceptualization of "natural resources" and "management." Marine Studies (MAST) 9(1):13-40. [online] URL: http://www.marecentre.n1/mast/documents/Mastvol9nol_Berkes. pdf

Berkhout, F., J. Hertin, and A. Jordan. 2002. Socio-economic futures in climate change impact assessment: using scenarios as 'learning machines.' Global Environmental Change 12(2):83-95. https://doi.org/10.1016/S0959-3780(02)00006-7

Bidwell, D., T. Dietz, and D. Scavia. 2013. Fostering knowledge networks for climate adaptation. Nature Climate Change 3:610-611. https://doi.org/10.1038/nclimate1931

Biedenweg, K., and N. D. Gross-Camp. 2018. A brave new world: integrating well-being and conservation. Ecology and Society 23 (2):32. https://doi.org/10.5751/ES-09977-230232

Brechin, S. R., P. R. Wilshusen, C. L. Fortwangler, and P. C. West. 2002. Beyond the square wheel: toward a more comprehensive understanding of biodiversity conservation as social and political process. Society and Natural Resources 15(1):41-64. https://doi. org/10.1080/089419202317174011

Bryant, M., M. Cheater, L. Hinds, and N. Matson. 2012. National wildlife refuges and sea-level rise: lessons from the frontlines. Defenders of Wildlife, Washington, D.C., USA. [online] URL: https://defenders.org/sites/default/files/publications/national-wildliferefuges-and-sea-level-rise.pdf

Burnett, P. 1976. Behavioral geography and the philosophy of mind. Pages 23-48 in G. Golledge and R. G. Ruston, editors. Spatial choice and spatial behavior. Ohio State University Press, Columbus, Ohio, USA.

Camillus, J. C. 2008. Strategy as a wicked problem. Harvard Business Review (May):99-106. [online] URL: https://hbr. org/2008/05/strategy-as-a-wicked-problem

Canter, D. 1977. The psychology of place. St. Martin, New York, New York, USA.

Carlsen, H., K. H. Dreborg, and P. Wikman-Svahn. 2013. Tailormade scenario planning for local adaptation to climate change. Mitigation and Adaptation Strategies for Global Change 18 (8):1239-1255. https://doi.org/10.1007/s11027-012-9419-x

Cheng, A. S., L. E. Kruger, and S. E. Daniels. 2003. "Place" as an integrating concept in natural resource politics: propositions for a social science research agenda. Society and Natural Resources 16(2):87-104. https://doi.org/10.1080/08941920309199

Clark, W. C., J. Jager, J. van Eijndhoven, and N. Dickson. 2001. Learning to manage global environmental risks: a comparative history of social responses to climate change, ozone depletion, and acid rain. MIT Press, Cambridge, Massachusetts, USA. 
Cobb, A. N., and J. L. Thompson. 2012. Climate change scenario planning: a model for the integration of science and management in environmental decision-making. Environmental Modelling and Software 38:296-305. https://doi.org/10.1016/j.envsoft.2012.06.012

Cox, R. 2012. Environmental communication and the public sphere. Sage, Thousand Oaks, California, USA.

Crane, T. A. 2010. Of models and meanings: cultural resilience in social-ecological systems. Ecology and Society 15(4):19. http:// dx.doi.org/10.5751/ES-03683-150419

Cumming, G. S., D. H. M. Cumming, and C. L. Redman. 2006. Scale mismatches in social-ecological systems: causes, consequences, and solutions. Ecology and Society 11(1):14. https://doi.org/10.5751/ES-01569-110114

Cumming, G. S., P. Olsson, F. S. Chapin, III, and C. S. Holling. 2013. Resilience, experimentation, and scale mismatches in socialecological landscapes. Landscape Ecology 28(6):1139-1150. https://doi.org/10.1007/s10980-012-9725-4

Czech, B., S. Covington, T. M. Crimmins, J. A. Ericson, C. Flather, M. Gale, K. Gerst, M. Higgins, M. Kaib, E. Marino, T. Moran, J. Morton, N. Niemuth, H. Peckett, D. Savignano, L. Saperstein, S. Skorupa, E. Wagener, B. Wilen, and B. Wolfe. 2014. Planning for climate change on the National Wildlife Refuge SystemM. U. S. Fish and Wildlife Service, National Wildlife Refuge System, Washington, D.C., USA. [online] URL: https://www.fs.fed.us/rm/ pubs journals/2014/rmrs 2014 czech b001.pdf

Daniels, R. C., T. W. White, and K. K. Chapman. 1993. Sea-level rise: destruction of threatened and endangered species habitat in South Carolina. Environmental Management 17(3):373-385. https://doi.org/10.1007/BF02394680

Demeritt, D. 2002. What is the 'social construction of nature'? A typology and sympathetic critique. Progress in Human Geography 26(6):767-790. https://doi.org/10.1191/0309132502ph402oa

Dietz, T., E. Ostrom, and P. C. Stern. 2003. The struggle to govern the commons. Science 302(5652):1907-1912. https://doi. org/10.1126/science.1091015

Duinker, P. N., and L. A. Greig. 2007. Scenario analysis in environmental impact assessment: improving explorations of the future. Environmental Impact Assessment Review 27(3):206-219. https://doi.org/10.1016/j.eiar.2006.11.001

Eaton, M. J., S. Yurek, Z. Haider, J. Martin, F. A. Johnson, B. J. Udell, H. Charkhgard, and C. Kwon. 2019. Spatial conservation planning under uncertainty: adapting to climate change risks using modern portfolio theory. Ecological Applications 29:e01962. https://doi.org/10.1002/eap.1962

Engle, N. L. 2011. Adaptive capacity and its assessment. Global Environmental Change 21(2):647-656. https://doi.org/10.1016/j. gloenvcha.2011.01.019

Faulkenberry, L., J. Coggeshall, K. Backman, and S. Backman. 2000. A culture of servitude: the impact of tourism and development on South Carolina's coast. Human Organization 59 (1):86-95. https://doi.org/10.17730/humo.59.1.353730461t724j02

Fertel, C., O. Bahn, K. Vaillancourt, and J.-P. Waaub. 2013. Canadian energy and climate policies: a SWOT analysis in search of federal/provincial coherence. Energy Policy 63:1139-1150. https://doi.org/10.1016/j.enpol.2013.09.057

Folke, C. 2006. Resilience: the emergence of a perspective for social-ecological systems analyses. Global Environmental Change 16(3):253-267. https://doi.org/10.1016/j.gloenvcha.2006.04.002

Frank, T. 2016. The US in a changing world order. Society 53 (5):531-537. https://doi.org/10.1007/s12115-016-0061-1

Gardels, N., and N. Berggruen. 2017. Salvaging globalization. New Perspectives Quarterly 34(1):67-79. https://doi.org/10.1111/ npqu. 12070

Gardner, L. R., W. K. Michener, T. M. Williams, E. R. Blood, B. Kjerve, L. A. Smock, D. J. Lipscomb, and C. Gresham. 1992. Disturbance effects of hurricane Hugo on a pristine coastal landscape: North Inlet, South Carolina, USA. Netherlands Journal of Sea Research 30:249-263. https://doi.org/10.1016/0077-7579 (92)90063-K

Ghazinoory, S., M. Abdi, and M. Azadegan-Mehr. 2011. SWOT methodology: a state-of-the-art review for the past, a framework for the future. Journal of Business Economics and Management 12 (1):24-48. https://doi.org/10.3846/16111699.2011.555358

Goodwin, P., and G. Wright. 2014. Decision analysis for management judgment. Fifth edition. John Wiley and Sons, New York, New York, USA.

Griffith, B., J. M. Scott, R. Adamcik, D. Ashe, B. Czech, R. Fischman, P. Gonzalez, J. Lawler, A. D. McGuire, and A. Pidgorna. 2009. Climate change adaptation for the US National Wildlife Refuge System. Environmental Management 44 (6):1043-1052. https://doi.org/10.1007/s00267-009-9323-7

Gunderson, L. H., and C. S. Holling. 2002. Panarchy: understanding transformations in human and natural systems. Island, Washington, D.C., USA.

Gunderson, L. H., C. S. Holling, and S. S. Light. 1995. Barriers and bridges to the renewal of ecosystems and institutions. Columbia University Press, New York, New York, USA.

Halfacre, A. C. 2013. A delicate balance: constructing a conservation culture in the South Carolina Lowcountry. University of South Carolina Press, Columbia, South Carolina, USA. https://doi.org/10.2307/j.ctv6wgh72

Hall, J. W., R. J. Lempert, K. Keller, A. Hackbarth, C. Mijere, and D. J. McInerney. 2012. Robust climate policies under uncertainty: a comparison of robust decision making and infogap methods. Risk Analysis 32(10):1657-1672. https://doi. org/10.1111/j.1539-6924.2012.01802.x

Harrison, C. M., and J. Burgess. 1994. Social constructions of nature: a case study of conflicts over the development of Rainham marshes. Transactions of the Institute of British Geographers 19 (3):291-310. https://doi.org/10.2307/622324

Haryono, F. E., and A. Ambariyanto. 2017. Genetic diversity approach to fishery management spiny lobster southern waters of java based on SWOT analysis and AHP. Omni-Akuatika 13 (1):26-33. https://doi.org/10.20884/1.oa.2017.13.1.163

Haynes, F. 2018. Trust and the community of inquiry. Educational Philosophy and Theory 50(2):144-151. https://doi. org/10.1080/00131857.2016.1144169 
Hegger, D., and C. Dieperink. 2014. Toward successful joint knowledge production for climate change adaptation. Ecology and Society 19(2):34. https://doi.org/10.5751/es-06453-190234

Hein, L., K. van Koppen, R. S. de Groot, and E. C. van Ierland. 2006. Spatial scales, stakeholders and the valuation of ecosystem services. Ecological Economics 57(2):209-228. https://doi. org/10.1016/j.ecolecon.2005.04.005

Helms, M. M., and J. Nixon. 2010. Exploring SWOT analysis where are we now? A review of academic research from the last decade. Journal of Strategy and Management 3(3):215-251. https://doi.org/10.1108/17554251011064837

Holling, C. S. 2001. Understanding the complexity of economic, ecological, and social systems. Ecosystems 4:390-405. https://doi. org/10.1007/s10021-001-0101-5

Hong, C.-W., and N.-W. Chan. 2010. Strength-weaknessopportunities-threats analysis of Penang National Park for strategic ecotourism management. World Applied Sciences Journal 10:136-145. [online] URL: http://www.idosi.org/wasj/ wasj10(T\&H)2010/17.pdf

Hulme, M. 2010. Problems with making and governing global kinds of knowledge. Global Environmental Change 20(4):558-564. https://doi.org/10.1016/j.gloenvcha.2010.07.005

Iguchi, J. 2011. Improving the improvement act: climate change management in the National Wildlife Refuge System. Environs 34:247-269. [online] URL: https://law.ucdavis.edu/centers/ environmental/files/Doremus $\% 20$ Writing $\% 20$ Winners/2010Iguchi. pdf

Ison, R. 2010. Systems practice: how to act in a climate change world. Springer Science Business Media, London, UK. https:// doi.org/10.1007/978-1-84996-125-7

Jasanoff, S. 2004. States of knowledge: the co-production of science and the social order. Routledge, New York, New York, USA. https://doi.org/10.4324/9780203413845

Jepson, P., M. Barua, and K. Buckingham. 2011. What is a conservation actor? Conservation and Society 9(3):229-235. https://doi.org/10.4103/0972-4923.86993

Johnson, C. Y., and M. F. Floyd. 2006. A tale of two towns: black and white municipalities respond to urban growth in the South Carolina Lowcountry. Human Ecology Review 13(1):23-38. [online] URL: https://www.srs.fs.usda.gov/pubs/ja/ja johnson016. pdf

Johnson, C. Y., A. C. Halfacre, and P. T. Hurley. 2009. Resistant place identities in rural Charleston County, South Carolina: cultural, environmental, and racial politics in the Sewee to Santee area. Human Ecology Review 16(1):1-16. [online] URL: https:// www.srs.fs.usda.gov/pubs/ja/2009/ja 2009 johnson 001.pdf

Johnson, F. A., D. J. Case, and D. D. Humburg. 2016. Learning and adaptation in waterfowl conservation: by chance or by design? Wildlife Society Bulletin 40(3):423-427. https://doi.org/10.1002/ wsb. 682

Johnson, F. A., M. J. Eaton, G. McMahon, R. Nilius, M. R. Bryant, D. J. Case, J. Martin, N. J. Wood, and L. Taylor. 2015. Global change and conservation triage on National Wildlife
Refuges. Ecology and Society 20(4):14. https://doi.org/10.5751/ ES-07986-200414

Kajanus, M., P. Leskinen, M. Kurttila, and J. Kangas. 2012. Making use of MCDS methods in SWOT analysis--lessons learnt in strategic natural resources management. Forest Policy and Economics 20:1-9. https://doi.org/10.1016/j.forpol.2012.03.005

Karvetski, C. W., J. H. Lambert, J. M. Keisler, and I. Linkov. 2011. Integration of decision analysis and scenario planning for coastal engineering and climate change. Systems, Man and Cybernetics, Part A: Systems and Humans 41(1):63-73. https://doi.org/10.1109/ TSMCA.2010.2055154

Keeney, R. L. 1992. Value-focused thinking: a path to creative decisionmaking. Harvard University Press, Cambridge, Massachusetts, USA.

Klenk, N. L., K. Meehan, S. L. Pinel, F. Mendez, P. T. Lima, and D. M. Kammen. 2015. Stakeholders in climate science: beyond lip service? Science 350(6262):743-744. https://doi.org/10.1126/ science.aab1495

Kollmuss, A., and J. Agyeman. 2002. Mind the gap: why do people act environmentally and what are the barriers to proenvironmental behavior? Environmental Education Research 8 (3):239-260. https://doi.org/10.1080/13504620220145401

Krysanova, V., C. Dickens, J. Timmerman, C. Varela-Ortega, M. Schlüter, K. Roest, P. Huntjens, F. Jaspers, H. Buiteveld, E. Moreno, J. de Pedraza Carrera, R. Slámová, M. Martínková, I. Blanco, P. Esteve, K. Pringle, C. Pahl-Wostl, and P. Kabat. 2010. Cross-comparison of climate change adaptation strategies across large river basins in Europe, Africa and Asia. Water Resources Management 24(14):4121-4160. https://doi.org/10.1007/s11269-010-9650-8

Lambin, E. F., and P. Meyfroidt. 2011. Global land use change, economic globalization, and the looming land scarcity. Proceedings of the National Academy of Sciences 108 (9):3465-3472. https://doi.org/10.1073/pnas.1100480108

Lambin, E. F., B. L. Turner, H. J. Geist, S. B. Agbola, A. Angelsen, J. W. Bruce, O. T. Coomes, R. Dirzo, G. Fischer, C. Folke, P. S. George, K. Homewood, J. Imbernon, R. Leemans, X. Li, E. F. Moran, M. Mortimore, P. S. Ramakrishnan, J. F. Richards, H. Skånes, W. Steffen, G. D. Stone, U. Svedin, T. A. Veldkamp, C. Vogel, and J. Xu. 2001. The causes of land-use and land-cover change: moving beyond the myths. Global Environmental Change 11(4):261-269. https://doi.org/10.1016/S0959-3780(01)00007-3

Lempert, R. J., and M. E. Schlesinger. 2000. Robust strategies for abating climate change. Climatic Change 45(3/4):387-401.

Levin, S. 1999. Fragile dominion: complexity and the commons. Perseus, Reading, Massachusetts, USA.

Ludwig, D. 2001. The era of management is over. Ecosystems 4:758-764. https://doi.org/10.1007/s10021-001-0044-x

Mace, G. M. 2014. Whose conservation? Science 345 (6204):1558-1560. https://doi.org/10.1126/science.1254704

Magness, D. R., A. L. Lovecraft, and J. M. Morton. 2012. Factors influencing individual management preferences for facilitating adaptation to climate change within the National Wildlife Refuge System. Wildlife Society Bulletin 36(3):457-468. https://doi. org/10.1002/wsb.156 
Marino, E., C. Hernando, R. Planelles, J. Madrigal, M. Guijarro, and A. Sebastián. 2014. Forest fuel management for wildfire prevention in Spain: a quantitative SWOT analysis. International Journal of Wildland Fire 23(3):373-384. https://doi.org/10.1071/ $\underline{\mathrm{WF} 12203}$

Martin, A., S. McGuire, and S. Sullivan. 2013. Global environmental justice and biodiversity conservation. Geographical Journal 179(2):122-131. https://doi.org/10.1111/geoj.12018

Meadow, A. M., D. B. Ferguson, Z. Guido, A. Horangic, G. Owen, and T. Wall. 2015. Moving toward the deliberate coproduction of climate science knowledge. Weather, Climate, and Society 7(2):179-191. https://doi.org/10.1175/WCASD-14-00050.1

Meyfroidt, P., E. F. Lambin, K.-H. Erb, and T. W. Hertel. 2013. Globalization of land use: distant drivers of land change and geographic displacement of land use. Current Opinion in Environmental Sustainability 5(5):438-444. https://doi.org/10.1016/ j.cosust.2013.04.003

Millett, S. M. 1988. How scenarios trigger strategic thinking. Long Range Planning 21(5):61-68. https://doi.org/10.1016/0024-6301 (88)90106-9

Mitchell, R. B., W. C. Clark, D. W. Cash, and F. Alcock. 2004. Science, scientists, and the policy process: lessons from global environmental assessments for the northwest forest. Pages 95-111 in K. Arabas and J. Bowersox, editors. Forest futures: science, politics and policy for the next century. Rowman and Littlefield, Lanham, Maryland, USA.

Montibeller, G., H. Gummer, and D. Tumidei. 2006. Combining scenario planning and multi-criteria decision analysis in practice. Journal of Multi-Criteria Decision Analysis 14(1-3):5-20. https:// doi.org/10.1002/mcda.403

Morris, J. T., P. V Sundareshwar, C. T. Nietch, B. Kjerfve, and D. R. Cahoon. 2002. Responses of coastal wetlands to rising sea level. Ecology 83(10):2869-2877. https://doi.org/10.1890/0012-9658 (2002)083[2869:ROCWTR]2.0.CO;2

National Park Service. 2013. Using scenarios to explore climate change: a handbook for practitioners. National Park Service Climate Change Response Program, Fort Collins, Colorado, USA. [online] URL: https://www.nps.gov/parkhistory/online books/ climate/CCScenariosHandbookJuly2013.pdf

Ney, S., and M. Thompson. 2000. Cultural discourses in the global climate change debate. Pages 65-92 in E. Jochem, J. Sathaye, and D. Bouille, editors. Society, Behaviour, and Climate Change Mitigation. Springer, Dordrecht, The Netherlands. https://doi. org/10.1007/0-306-48160-X 2

Nisbet, E. K. L., and M. L. Gick. 2008. Can health psychology help the planet? Applying theory and models of health behaviour to environmental actions. Canadian Psychology 49(4):296-303. https://doi.org/10.1037/a0013277

Norberg, J., J. Wilson, B. Walker, and E. Ostrum. 2008. Diversity and resilience of socio-ecological systems. Pages 46-79 in $\mathrm{J}$. Norberg and G. S. Cumming, editors. Complexity theory for a sustainable future. Columbia University Press, New York, New York, USA.
Nyarku, K., and G. Agyapong. 2011. Rediscovering SWOT analysis: the extended version. Academic Leadership Journal 9 (2):28. [online] URL: https://scholars.fhsu.edu/cgi/viewcontent. cgi article $=1666 \&$ context $=$ alj

Olsson, P., C. Folke, and F. Berkes. 2004. Adaptive comanagement for building resilience in social-ecological systems. Environmental Management 34(1):75-90. https://doi.org/10.1007/s00267-003-0101-7

Olsson, P., L. H. Gunderson, S. R. Carpenter, P. Ryan, L. Lebel, C. Folke, and C. S. Holling. 2006. Shooting the rapids: navigating transitions to adaptive governance of social-ecological systems. Ecology and Society 11(1):18. https://doi.org/10.5751/ES-01595-110118

Pahl-Wostl, C. 2009. A conceptual framework for analysing adaptive capacity and multi-level learning processes in resource governance regimes. Global Environmental Change 19(3):354-365. https://doi.org/10.1016/j.gloenvcha.2009.06.001

Paloniemi, R., E. Apostolopoulou, E. Primmer, M. GrodzinskaJurcak, K. Henle, I. Ring, M. Kettunen, J. Tzanopoulos, S. Potts, S. van den Hove, P. Marty, A. McConville, and J. Similä. 2012. Biodiversity conservation across scales: lessons from a sciencepolicy dialogue. Nature Conservation 2:7-19. https://doi. org/10.3897/natureconservation.2.3144

Peterson, G. D., G. S. Cumming, and S. R. Carpenter. 2003. Scenario planning: a tool for conservation in an uncertain world. Conservation Biology 17(2):358-366. https://doi.org/10.1046/ j.1523-1739.2003.01491.x

Pickton, D. W., and S. Wright. 1998. What's swot in strategic analysis? Strategic Change 7(2):101-109. https://doi.org/10.1002/(sici) 1099-1697(199803/04)7:2<101::aid-jsc332>3.0.co;2-6

Prochaska, J. O., and W. F. Velicer. 1997. The transtheoretical model of health behavior change. American Journal of Health Promotion 12(1):38-48. https://doi.org/10.4278/0890-1171-12.1.38

Rayner, S., and E. L. Malone. 1997. Zen and the art of climate maintenance. Nature 390:332-334. https://doi.org/10.1038/36975

Rittel, H. W. J., and M. M. Webber. 1973. Dilemmas in a general theory of planning. Policy Sciences 4(2):155-169. https://doi. org/10.1007/bf01405730

Rosentrater, L. D. 2010. Representing and using scenarios for responding to climate change. Wiley Interdisciplinary Reviews: Climate Change 1(2):253-259. https://doi.org/10.1002/wcc.32

Rounsevell, M. D. A., and M. J. Metzger. 2010. Developing qualitative scenario storylines for environmental change assessment. Wiley Interdisciplinary Reviews: Climate Change 1 (4):606-619. https://doi.org/10.1002/wcc.63

Scherr, S. J., and J. A. McNeely. 2008. Biodiversity conservation and agricultural sustainability: towards a new paradigm of 'ecoagriculture' landscapes. Philosophical Transactions of the Royal Society B: Biological Sciences 363(1491):477-494. https:// doi.org/10.1098/rstb.2007.2165

Schuttenberg, H. Z., and H. K. Guth. 2015. Seeking our shared wisdom. Ecology and Society 20(1):15. http://dx.doi.org/10.5751/ ES-07038-200115

Semenza, J. C., D. E. Hall, D. J. Wilson, B. D. Bontempo, D. J. Sailor, and L. A. George. 2008. Public perception of climate 
change: voluntary mitigation and barriers to behavior change. American Journal of Preventive Medicine 35(5):479-487. https:// doi.org/10.1016/j.amepre.2008.08.020

Sheppard, S. R. J., A. Shaw, D. Flanders, S. Burch, A. Wiek, J. Carmichael, J. Robinson, and S. Cohen. 2011. Future visioning of local climate change: a framework for community engagement and planning with scenarios and visualisation. Futures 43 (4):400-412. https://doi.org/10.1016/j.futures.2011.01.009

Shoreman-Ouimet, E., and H. Kopnina. 2015. Reconciling ecological and social justice to promote biodiversity conservation. Biological Conservation 184:320-326. https://doi.org/10.1016/j. biocon.2015.01.030

Siaosi, F., H.-W. Huang, and C.-T. Chuang. 2012. Fisheries development strategy for developing Pacific Island countries: case study of Tuvalu. Ocean and Coastal Management 66:28-35. https://doi.org/10.1016/j.ocecoaman.2012.04.021

Stanley, D. 2003. What do we know about social cohesion: the research perspective of the federal government's social cohesion research network. Canadian Journal of Sociology/Cahiers canadiens de sociologie 28(1):5-17. https://doi.org/10.2307/3341872

Stedman, S.-M., and T. E. Dahl. 2008. Status and trends of wetlands in the coastal watersheds of the eastern United States, 1998 to 2004. U.S. Dept. of the Interior, U.S. Fish and Wildlife Service, Washington, D.C., USA. [online] URL: https://www.fws. gov/wetlands/documents/Status-and-Trends-of-Wetlands-in-theCoastal-Watersheds-of-the-Eastern-United-States-1998-to-2004. pdf

Stutz, M. L., and O. H. Pilkey. 2011. Open-ocean barrier islands: global influence of climatic, oceanographic, and depositional settings. Journal of Coastal Research 27:207-222. https://doi. org/10.2112/09-1190.1

Swan, K., and P. Ice. 2010. The community of inquiry framework ten years later: introduction to the special issue. Internet and Higher Education 13:1-4. https://doi.org/10.1016/j.iheduc.2009.11.003

Tompkins, E. L., R. Few, and K. Brown. 2008. Scenario-based stakeholder engagement: incorporating stakeholders preferences into coastal planning for climate change. Journal of Environmental Management 88(4):1580-1592. https://doi.org/10.1016/j. jenvman.2007.07.025

U.S. Fish and Wildlife Service. 2010. Rising to the urgent challenge: strategic plan for responding to accelerating climate change. U.S. Fish and Wildlife Service, Washington, D. C., USA. [online] URL: https://www.cakex.org/sites/default/files/documents/USFWS_Strategic $\%$ 20Plan $\% 20$ for $\% 20$ Responding $\% 20$ to $\% 20$ Accelerating $\% 20$ Climate $\%$ 20Change 2010.pdf

U.S. Global Change Research Program (USGRCP). 2018. Impacts, risks, and adaptation in the United States: the fourth national climate assessment, Volume II. Global Change Research Program, Washington, D.C., USA. https://doi.org/10.7930/ nca4.2018.fm

Verweij, M., M. Douglas, R. Ellis, C. Engel, F. Hendriks, S. Lohmann, S. Ney, S. Rayner, and M. Thompson. 2006. Clumsy solutions for a complex world: the case of climate change. Public Administration 84(4):817-843. https://doi.org/10.1111/

j.1540-8159.2005.09566.x-i1
Walker, B., and D. Salt. 2006. Resilience thinking: sustaining ecosystems and people in a changing world. Island, Washington, D.C., USA.

Weaver, C. P., S. Mooney, D. Allen, N. Beller-Simms, T. Fish, A. E. Grambsch, W. Hohenstein, K. Jacobs, M. A. Kenney, M. A. Lane, L. Langner, E. Larson, D. L. McGinnis, R. H. Moss, L. G. Nichols, C. Nierenberg, E. A. Seyller, P. C. Stern, and R. Winthrop. 2014. From global change science to action with social sciences. Nature Climate Change 4:656. https://doi.org/10.1038/ nclimate2319

Weihrich, H. 1982. The TOWS matrix - a tool for situational analysis. Long Range Planning 15(2):54-66. https://doi. org/10.1016/0024-6301(82)90120-0

Wiseman, J., C. Biggs, L. Rickards, and T. Edwards. 2011. Scenarios for climate adaptation: guidebook for practitioners. University of Melbourne, Carlton, Victoria, Australia. [online] URL: http://www.vcccar.org.au/sites/default/files/publications/ SPCA GUIDEBOOK FINAL 200711.pdf

Wright, G., R. Bradfield, and G. Cairns. 2013. Does the intuitive logics method - and its recent enhancements - produce "effective" scenarios? Technological Forecasting and Social Change 80 (4):631-642. https://doi.org/10.1016/j.techfore.2012.09.003 
Appendix 1. Internet resources provided to participants prior to the scenario planning workshop.

\begin{tabular}{|c|c|c|}
\hline \multicolumn{2}{|c|}{ Resource } & 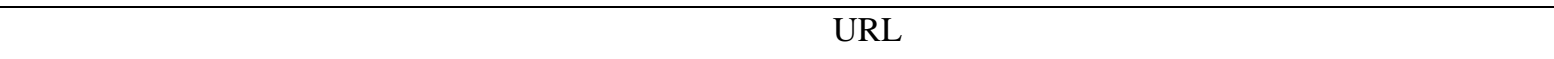 \\
\hline \multirow{3}{*}{$\begin{array}{l}\text { NOAA } \\
\text { Coastal } \\
\text { County } \\
\text { Snapshots - } \\
\text { Charleston } \\
\text { County }\end{array}$} & Flood exposure & $\underline{\text { https://coast.noaa.gov/snapshots/\#/process?action=flood\&state=45\&county=019\&bounds=null }}$ \\
\hline & $\begin{array}{l}\text { Wetlands } \\
\text { benefits }\end{array}$ & https://coast.noaa.gov/snapshots/\#/process?action=wetlands\&state $=45 \&$ county $=019 \&$ bounds $=$ null \\
\hline & Ocean jobs & https://coast.noaa.gov/snapshots/\#/process?action=ocean\&state $=45 \&$ county $=019 \&$ bounds $=$ null \\
\hline $\begin{array}{l}\text { Charleston } \\
\text { Metro } \\
\text { Chamber of } \\
\text { Commerce }\end{array}$ & $\begin{array}{l}\text { Population } \\
\text { growth trends }\end{array}$ & http://web.charlestonchamber.net/external/wcpages/wcwebcontent/webcontentpage.aspx?contentid=25377 \\
\hline $\begin{array}{l}\text { University of } \\
\text { North } \\
\text { Carolina: } \\
\text { Carolina } \\
\text { demography }\end{array}$ & $\begin{array}{l}\text { Population } \\
\text { growth }\end{array}$ & http://demography.cpc.unc.edu/2015/12/08/population-growth-in-the-carolinas-projected-vs-observed-trends/ \\
\hline $\begin{array}{l}\text { South } \\
\text { Carolina } \\
\text { Revenue and } \\
\text { Fiscal Affairs } \\
\text { Office }\end{array}$ & Net migration & http://www.sccommunityprofiles.org/census/netmigration_c2010.html \\
\hline $\begin{array}{l}\text { Charleston } \\
\text { County }\end{array}$ & $\begin{array}{l}\text { Comprehensive } \\
\text { Plan }\end{array}$ & https://www.charlestoncounty.org/departments/zoning-planning/files/histcompplan/May-8-2017_Materials.pdf \\
\hline $\begin{array}{l}\text { Center for } \\
\text { Disease } \\
\text { Control }\end{array}$ & $\begin{array}{l}\text { Social } \\
\text { vulnerability }\end{array}$ & https://svi.cdc.gov/Documents/CountyMaps/2014/South\%20Carolina/SouthCarolina2014_Charleston.pdf \\
\hline
\end{tabular}


Appendix 1. Continued.

\begin{tabular}{|c|c|c|}
\hline \multicolumn{2}{|c|}{ Resource } & URL \\
\hline $\begin{array}{l}\text { South Carolina } \\
\text { Sea Grant }\end{array}$ & $\begin{array}{l}\text { Climate } \\
\text { change effects }\end{array}$ & http://www.scseagrant.org/pdf_files/Climate-Fact-Sheet-8-13-2014.pdf \\
\hline $\begin{array}{l}\text { City of } \\
\text { Charleston }\end{array}$ & $\begin{array}{l}\text { Sea Level Rise } \\
\text { Strategy }\end{array}$ & http://www.charleston-sc.gov/DocumentCenter/View/10089 \\
\hline \multirow{2}{*}{$\begin{array}{l}\text { NOAA Tides } \\
\& \text { Currents }\end{array}$} & Sea level trend & https://tidesandcurrents.noaa.gov/sltrends/sltrends_station.shtml?stnid=8665530 \\
\hline & $\begin{array}{l}\text { Hurricane } \\
\text { Matthew water } \\
\text { levels }\end{array}$ & https://tidesandcurrents.noaa.gov/images/quicklook_high_wl/Hurricane_Matthew_2016.jpg \\
\hline $\begin{array}{l}\text { South Carolina } \\
\text { State } \\
\text { Climatology } \\
\text { Office }\end{array}$ & $\begin{array}{l}\text { Climate } \\
\text { Variability and } \\
\text { Impacts to } \\
\text { South } \\
\text { Carolina's } \\
\text { Natural } \\
\text { Resources: } \\
\text { Final } \\
\text { Workshop } \\
\text { Report }\end{array}$ & http://www.dnr.sc.gov/ccworkshops/pdf/WorkshopReportFINAL.pdf \\
\hline $\begin{array}{l}\text { Geographic } \\
\text { Research } \\
\text { Letters }\end{array}$ & $\begin{array}{l}\text { Headwater } \\
\text { erosion }\end{array}$ & http://onlinelibrary.wiley.com/doi/10.1029/2008GL036000/epdf \\
\hline $\begin{array}{l}\text { Environmental } \\
\text { Protection } \\
\text { Agency }\end{array}$ & $\begin{array}{l}\text { Synthesis of } \\
\text { Adaptation } \\
\text { Options for } \\
\text { Coastal Areas }\end{array}$ & https://www.epa.gov/sites/production/files/2014-04/documents/cre synthesis 1-09.pdf \\
\hline
\end{tabular}


Appendix 2. Future scenarios as developed by the Cape Romain Partnership for Coastal Protection in the Lowcountry of South Carolina.

The four scenarios depict two extreme and two intermediate futures. The figures associated with the following scenarios describe the characterization of the three principal driving forces. The colloquial names of the scenarios are intended as memes, which the Partnership may or may not find useful.

\section{Scenario 1: The Three Horsemen}

There is little or no effective global response to climate change, and the backlash to globalization deepens and spreads over the coming decades. The U.S. greatly increases military spending and therefore can afford less social services. Isolationist policies embroil the USA in trade wars (leading to increased tariffs and trade barriers) and other protectionist policies. Global order is chaotic. The Lowcountry in turn is plagued by social, economic, and political upheaval and increased polarization. Population growth continues, but fewer people are

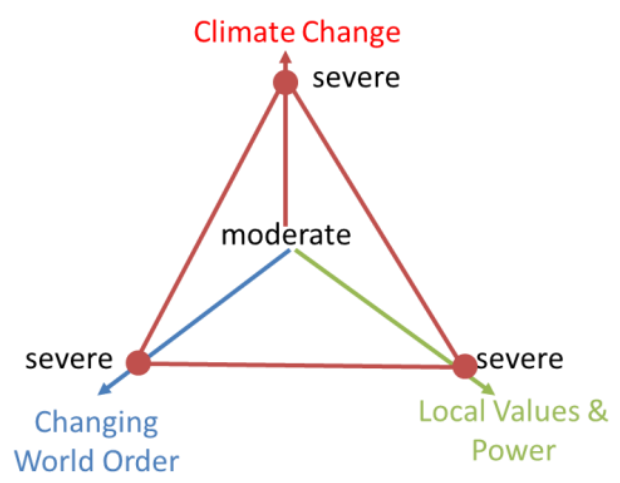
moving to the area by mid-century in response to declining environmental values and increasing coastal vulnerability. Society turns more inward looking, with politics becoming increasingly polarized, as people feel less in control of their lives. Local politics become less inclusive, less accountable, and more corrupt. People become more xenophobic; race relations become increasingly problematic. The gap between rich and poor continues to grow, adding to the breakdown of social cohesion. Tidal flooding and storm surge are a constant threat, impacting infrastructure and slowing economic growth. Local regulatory measures to combat local effects of climate change and urban sprawl are largely too little, too late. A sense of place and appreciation of cultural heritage declines, making community-based solutions increasingly difficult to attain. Unincorporated areas of Charleston County are particularly hard-hit; McClellanville is largely abandoned to the sea. Response to sea level rise comes largely in the form of coastal hardening to protect development and infrastructure. Ecotourism declines, and marine transportation jobs are hard-hit by increased tariffs and trade barriers. Economic growth is driven mainly by the health sector and increased military spending. Large segments of the population are increasingly vulnerable due to ageing of immigrant retirees, rural gentrification and lack of affordable housing, exposure to the impacts of climate change, and the inability of public services to keep pace with the rapid changes affecting the area.

There is extensive environmental degradation by mid-century from a combination of unregulated growth, climate change, and the power wielded by commercial interests. Impacts include the rapid loss of barrier islands, accompanied by rapid conversion of marshlands to open water, in 
turn diminishing the value of commercial and recreational fisheries. The loss of barrier islands also reduces habitat available to migratory birds and sea turtles. Water quality degradation (especially increases in coliform bacteria and salinity) leads to the commercial collapse of oyster and blue crab fisheries. Competition for clean, freshwater intensifies due to more frequent droughts and population growth throughout the state. Changes in precipitation patterns and increased flooding result in increased mosquito populations in low-lying areas, leading to higher risk of insect borne disease outbreaks. Rapid urbanization diminishes the aesthetic quality of the rural landscape and contributes to a decline in forestry.

\section{Scenario 2: United Front}

As in scenario 1, there is little or no effective global response to catastrophic climate change, and the backlash to globalization deepens and spreads over the coming decades; the U.S. greatly increases military spending and therefore can afford less social services; isolationist policies embroil the USA in trade wars (leading to increased tariffs and trade barriers) and other protectionist policies. Global order is chaotic, with shifting alliances and regional powers. Population continues to grow in the Lowcountry, at least through mid-century, attracting

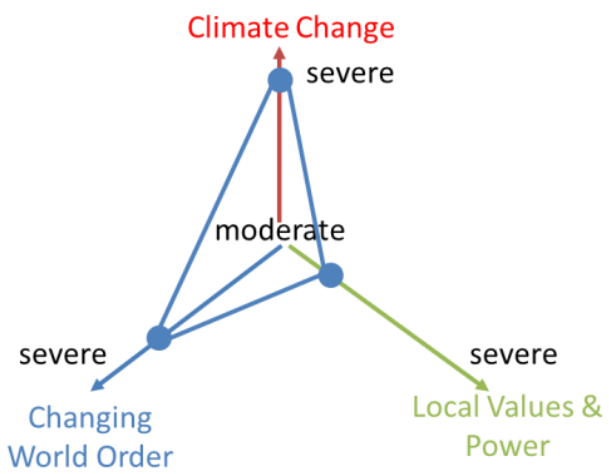
immigrants due to the desirability of the environment, culture, and lifestyle. Immigrants are anxious to maintain this lifestyle and so assimilate rapidly. This prevents a breakdown in social cohesion. Much of this social cohesion centers on appreciation for natural resources. Government focus is on local economic development. Due to isolationist policies, economic drivers are heavy-industry based (i.e. Volvo, Boeing, etc.). This is bringing in more workers (educated, skilled) and employs locals as well. However, this also leads to some displacement of locals. For example, many of the infrastructure/road building contractors are bringing in their own people (not hiring locals). On the other hand, supporting industries are stimulated by the large economic drivers, such as the timber industry, which largely employs local labor. This also results in more blue-collar jobs as other associated business opportunities arise (supporting industries: welding, construction, other types of entrepreneurship, etc.). This does not solve income inequality or the urban vs. rural divide hence there is a "mixed bag" of economic opportunity. Heavy industry increases demand for energy and ecosystem services. This increases the marginal value of ecosystem services, increases development, and increases property values, which can affect access to coastal resources and lead to loss of property for those who cannot afford to live in this area in the "new" economic climate. Local governments act as necessary to protect the social-ecological system. City planners/administrators improve water treatment facilities and limit coastal development through zoning policies. Mayors, city council make educated zoning decisions based on projected sea level rise, flood zones, elevation, etc., along 
with key community stakeholders; community-based planning is emphasized. Conservation organizations (all levels) form partnerships to expand the promotion and implementation of environmental education and environmental engagement. Lowcountry "Local First" does outreach to promote positive impacts of local economic stimulus. Other local organizations promote the positive human health and well-being impacts of consuming local, for example Charleston Good. NGOs and University cultural/historic departments organize training to encourage entrepreneurship to meet increased demand for local culture/heritage. The effectiveness of these activities is enhanced by a strong place identity and social cohesion.

The local effects of climate change on ecosystem goods and services are rather severe, however. An increased frequency of extreme events (rain bombs, drought, tropical storms) is placing severe strains on public safety, human infrastructure, agriculture, and natural resources. Due to the increased frequency/severity of storms (i.e. rain bombs), more impervious cover affects storm water runoff as natural drainage systems are disrupted, providing less opportunity for carbon sequestration. More runoff and less drainage have an impact on access to clean water and affect coastal habitats through erosion and upsetting normal sediment transport systems. A lack of drainage (standing water) has human health implications, resulting in an increased risk of outbreaks of insect borne diseases, and increased storm severity affects access to social services (hospitals, etc.). Bird and turtle nesting failures increase due to more intense storm events, which impact the ecosystem services that these species provide (bird watching, aesthetic value, tourism, "being immersed in wilderness" value). Changes in precipitation patterns lead to more severe periods of drought and infrequent but severe rain storms result in extreme pollutant loading. Saltwater intrusion impacts freshwater aquifers as well as shellfish habitat (oysters, blue crabs). Intrusion also changes marsh composition, which upsets the needs of habitat-dependent organisms.

\section{Scenario 3: Real Life}

Global action and national policies to reduce emissions are helping moderate the worst impacts of climate change globally. Although local impacts by mid-century are less than some had feared, they are still placing strains on the resilience of the Lowcountry social-ecological system. Population continues to grow over the next few decades, principally through movement of people from other areas, but then begins to moderate by mid-century due to the cumulative effects of global change and their impact on local ecosystem goods and services; this contributes to a

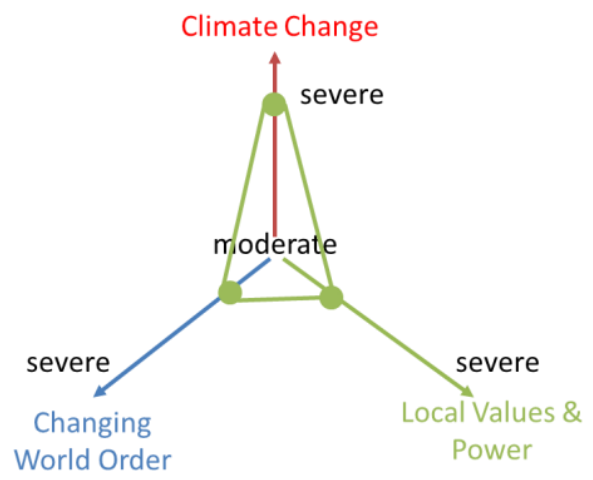
decline in a sense of place. Although the worst of global climate-change impacts have been 
avoided, local effects are still moderately high. Sea level continues to rise and tidal flooding is approaching 180 times per year in Charleston. Local governments assume a strong role in adaptation to global change, supporting education, providing incentives to landowners, and implementing policies to control growth and protect the population from disasters. Charleston is successful at implementing its "Sea Level Rise Strategy" of reinvestment, response, and readiness. Local services are also robust to help mitigate the health and infrastructure risks associated with such extremes in climate change. Efforts to stem the decline of social cohesion are being effective. Strong community-based action is led by conservation NGOs and local governments, with the support of federal partners including Francis Marion National Forest and Cape Romain National Wildlife Refuge. These groups and institutions provide and support education, communication, and awareness that are helping to bring people together to confront global change.

As seas continue to rise and water quality continues to decline, however, impacts are taking their toll on ecosystem goods and services, affecting freshwater supply and quality, fisheries, recreation, tourism, and biodiversity. Nonetheless, with federal, state, and local support, Francis Marion National Forest and Cape Romain National Wildlife Refuge secure additional properties through fee-title and easement to provide for marsh migration and to enhance habitat area and connectivity. Effective ways are found to use spoil for replenishing beaches and building nesting islands for migratory birds.

\section{Scenario 4: Manna}

Global action on climate change is strong and effective, in part driven by rapid advances in technology. Developed and developing nations come to agreements about how to share (and enforce) the costs of mitigation and adaptation. Democracy and participatory governance spread in a more stable world order, leading to a greater sense of individual empowerment. Nation states preserve their identities, but there is a greater awareness of our global interconnections and our responsibility to future generations.

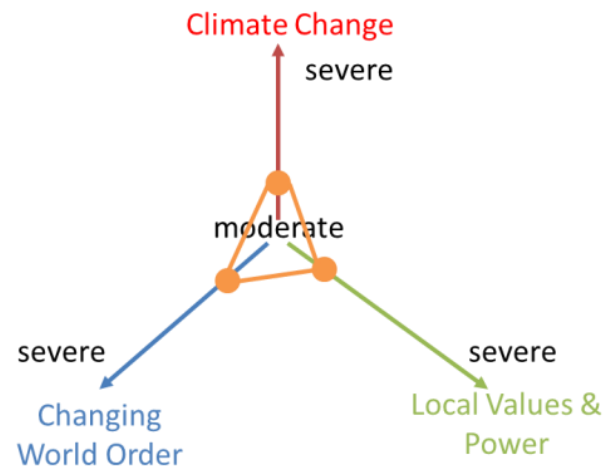
Local political power becomes more distributed, with NGOs, churches and other organizations playing a large role in generating community-based solutions. With support from the federal government (including Francis Marion National Forest, Cape Romain National Wildlife Refuge, and others), communities rely more on incentive-based adaptation measures and less on regulatory ones. Ecotourism continues to flourish, and marine transportation sees strong growth due to modern, fair-trade policies. Economic development is more egalitarian, with smart growth designed to protect a diversity of local values, especially abatement of flooding and 
storm surge. Federal funding is available to protect or retrofit infrastructure at risk due to global change, especially in Charleston to help prevent tidal flooding. Local communities support programs of adult education and training, and the area becomes more attractive to hi-tech industry. Social services are sufficient to support at-risk populations. Community cohesion is high due to desire to maintain Lowcountry local identities; this fosters support for local and sustainable products.

Less climate change and more geopolitical stability helps Lowcountry communities do better at protecting and preserving cultural values and local ecosystem goods and services. Less extreme changes in precipitation patterns leads to fewer threats to human health, and those threats that do emerge are more easily addressed through robust social services. Sea level rise continues and approaches 1 foot by midcentury and is the principal effect of climate change. Ecosystem goods and services are impacted by sea level rise and population growth, but society is spared the worst effects. Fisheries are negatively affected due to loss and degradation of habitat, especially commercial fisheries for oysters and blue crab. Recreational fishing continues to be a strong draw to the area. The timber industry remains viable, with longleaf restoration providing more resilient forests. Some threatened and endangered species do better (red-cockaded woodpecker) while others (sea turtles) continue to decline. Coastal populations of seabirds continue to decline due to widespread habitat loss on the Atlantic Coast. 